
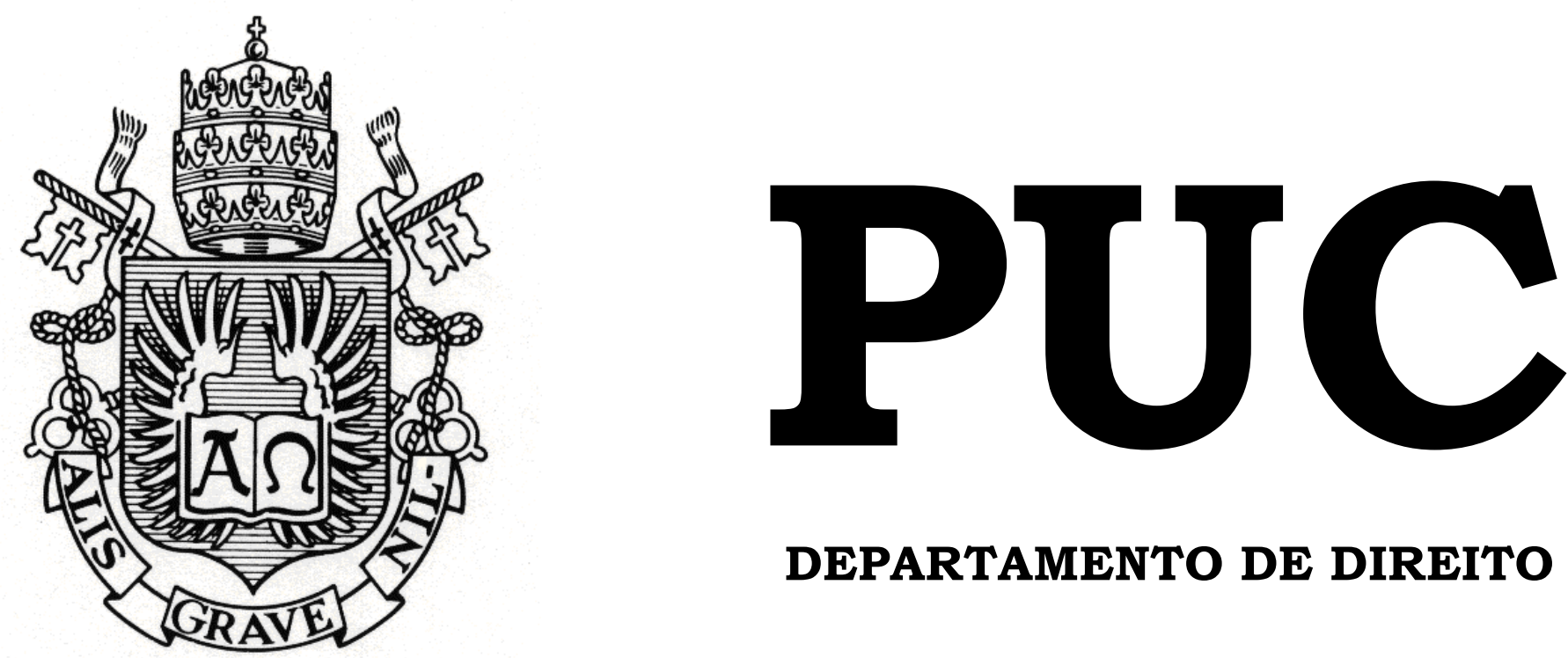

DEPARTAMENTO DE DIREITO

\title{
CLÁUSULA DE ELEIÇÃO DE FORO EM CONTRATOS INTERNACIONAIS: O QUE MUDA COM O NOVO CÓDIGO DE PROCESSO CIVIL
}

por

JOANA HOLZMEISTER E CASTRO

ORIENTADORA: Nádia de Araújo

2015.1

PONTIFÍCIA UNIVERSIDADE CATÓLICA DO RIO DE JANEIRO

RUA MARQUÊS DE SÃO VICENTE, 225 - CEP 22453-900

RIO DE JANEIRO - BRASIL 


\title{
CLÁUSULA DE ELEIÇÃO DE FORO EM CONTRATOS INTERNACIONAIS: O QUE MUDA COM O NOVO CÓDIGO DE PROCESSO CIVIL
}

\author{
por \\ JOANA HOLZMEISTER E CASTRO
}

Monografia

apresentada

ao

Departamento de Direito da Pontifícia Universidade Católica do Rio de Janeiro (PUC-Rio) para a obtenção do Título de Bacharel em Direito.

Orientador(a): Nádia de Araújo 


\section{AGRADECIMENTOS}

Primeiramente, gostaria de agradecer àqueles sem os quais nada disso seria possível. Àqueles que estão sempre do meu lado, me incentivando e encorajando, assim como os que certamente mais contribuem para a minha felicidade e sucesso, tanto pessoal quanto profissional: Raul e Sylvia, meus queridos e amados pais. Não há palavras para descrever o quanto eu sou agradecida por tudo.

Aos meus irmãos, Felipe e Luísa, companheiros e amigos, presentes em todos e quaisquer momentos. Nenhum agradecimento é suficiente para representar toda a importância que têm em minha vida.

À Gabriela Lôbo, Julia Laffitte e Rafaela Emery, pessoas especiais com quem a PUC- Rio me presenteou. Foram cinco anos que não teriam tido o mesmo significado sem cada uma delas. Sou agradecida pela amizade e cumplicidade que se formou em nós e que seguramente durará para o resto da vida.

Por fim, agradeço à Professora Nádia de Araújo, orientadora desta monografia. Agradeço a paciência, seriedade, divisão de conhecimentos, sabedoria e, principalmente, o tempo que dedicou com este trabalho que em muito contribuíram para a sua qualidade. 


\section{RESUMO}

Castro, Joana Holzmeister e. Cláusula de eleição de foro em contratos internacionais: o que muda com o Novo Código de Processo Civil. 57 p. Monografia (Graduação em Direito) - Pontifícia Universidade Católica do Rio de Janeiro: Rio de Janeiro, 2015.

O presente trabalho tem como objetivo promover uma análise de como a cláusula de eleição de foro era entendida e aplicada pela doutrina e pelos tribunais nacionais nos termos do artigo 88 do Código de Processo Civil de 1973 e explicar como a sua percepção muda com o Novo Código de Processo Civil.

Palavras- Chave: Direito Internacional Privado - Competência Internacional - Jurisdição - Estado Brasileiro - Processo Civil - Contrato Internacional Cláusula de Eleição de Foro - Autonomia das Partes. 


\section{SUMÁRIO}

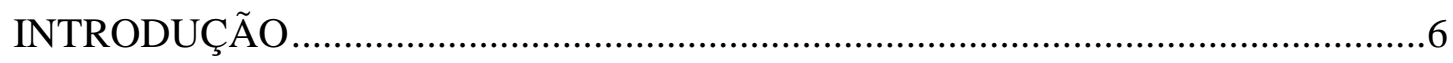

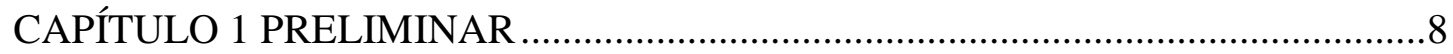

1.1 Competência Internacional ..............................................................

1.2 Competência Internacional Concorrente ....................................................12

CAPÍTULO 2 SITUAÇÃO ATUAL DO ARTIGO 88 NO CÓDIGO DE PROCESSO

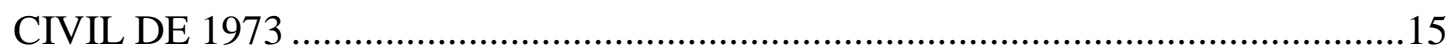

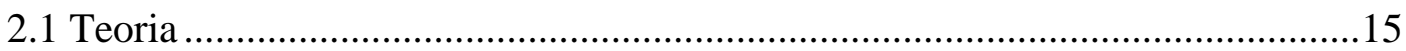

2.2 Eleição de Foro e Casos .................................................................................20

CAPÍTULO 3 ARTIGO 25 NO NOVO CÓDIGO DE PROCESSO CIVIL ................30

3.1 Convenção de Haia sobre acordo de eleição de foro de 2005 ............................30

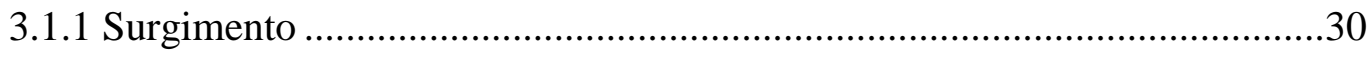

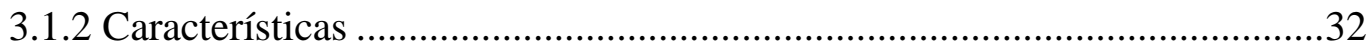

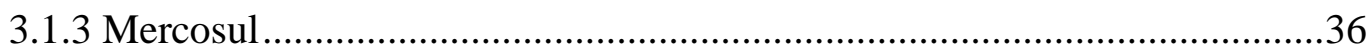

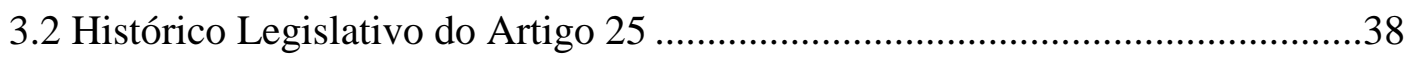

3.2.1 O Anteprojeto do Novo Código de Processo Civil .................................. 38

3.2.1.1 Considerações Gerais ........................................38

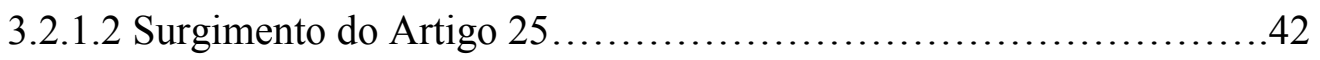

3.2.2 Projetos e Emendas .....................................................................43

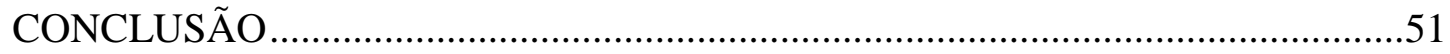

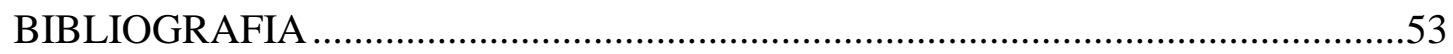




\section{Lista de Abreviatura e Siglas}

CPC

CRFB

STJ

TJRJ

TJRS

TJSP

REsp

PLS

PL

Art.

Artigo
Código de Processo Civil

Constituição da República Federativa do Brasil

Superior Tribunal de Justiça

Tribunal de Justiça do Rio de Janeiro

Tribunal de Justiça do Rio Grande do Sul

Tribunal de Justiça de São Paulo

Recurso Especial

Projeto de Lei do Senado

Projeto de Lei 


\section{INTRODUÇÃO}

Em matéria de contratos internacionais, a jurisdição se torna assunto de relevante importância, uma vez que pode suscitar dúvidas que podem dar azo a maiores controvérsias. Para garantir mais previsibilidade em questão de ordem processual, de onde e quem irá dirimir tal conflito, existe a cláusula de eleição de foro.

Ao se inserir uma cláusula de eleição de foro, que estabelece que país e qual de seus órgãos jurisdicionais será o competente para resolver a eventual lide internacional em questão, eliminam-se dúvidas quanto à jurisdição competente. A inserção de uma cláusula dessa natureza implica a aceitação das leis processuais do foro eleito, a não ser que exista outra cláusula que discipline a lei material aplicável ao contrato.

Em se tratando de competência internacional concorrente do Estado brasileiro, a cláusula de eleição de foro nem sempre teve a devida aceitação nos tribunais nacionais, embora reconhecida como ferramenta processual.

Com a sanção do Novo Código de Processo Civil, o cenário quanto à cláusula de eleição de foro muda. Enquanto antes a sua utilização não conferia certeza às partes que a estipulavam, agora o tema passa a ser pacífico, devido a inclusão no Código de um artigo que disciplina a matéria, o que confere segurança jurídica para seus optantes.

A presente monografia busca comparar o quadro anterior $\mathrm{e}$ posterior ao Novo Código de Processo Civil em relação a cláusula de eleição de foro em contratos internacionais. Para tal, foi necessário pesquisa doutrinária e jurisprudencial. Ademais, um extenso levantamento das versões dos projetos de leis que dariam ensejo ao 
Novo CPC foi realizada. Para tal, os sites do Senado Federal e da Câmara dos Deputados foram utilizados como instrumento de pesquisa.

Para melhor entender a complexidade da questão, o trabalho começa com uma parte preliminar que explica a competência internacional do Estado brasileiro, mais especificamente a competência concorrente que é a parte da competência internacional relevante para a cláusula de eleição de foro.

O capítulo seguinte explora a situação atual do artigo 88 no Código de Processo Civil de 1973, tanto teoricamente quanto na prática, de acordo com a jurisprudência. Este capítulo pode ser encarado como o antes.

O Capítulo 3, por sua vez, trata do artigo 25 do Novo Código de Processo Civil, que define a nova regra para a Justiça brasileira no que tange a cláusula de eleição de foro. Para melhor compreender como este surgiu, foi necessário abordar as inspirações do artigo no plano internacional e o seu histórico legislativo. Este capítulo deve ser encarado como o depois. 


\section{CAPÍTULO 1 PRELIMINAR}

\subsection{Competência Internacional}

O direito subjetivo de ajuizar uma ação, ou seja, o direito de ação corresponde à função estatal de jurisdição. Assim, o Estado cumpre o dever de, mediante provocação, garantir o devido processo legal e administrar a Justiça. De acordo com Liebman, chama-se de competência a "quantidade de jurisdição cujo exercício é atribuído a cada órgão ou grupo de órgãos" $"$. Dessa maneira, por meio de regras legais é conferido a cada órgão o desempenho de jurisdição através de um gradativo processo de concretização, até que se chegue ao juízo competente para determinado processo.

A estruturação dos órgãos judiciários de cada país é feita levando em consideração critérios próprios influenciados pelos rumos históricos do ordenamento jurídico nacional assim como o cenário do momento social e político do país. Num primeiro momento se cuida da competência internacional. Isto é, apenas se for considerada competente a Justiça brasileira é que se indagará a competência sucessiva interna (se é federal, estadual, trabalhista, etc.), determinando então, o foro e o juízo competentes. Logo, no que tange a jurisdição internacional, pode se entender que:

“(...) o legislador atribui ao juiz nacional, abstratamente, o poder de apreciar determinadas causas, excluindo as demais. Trata-se da chamada competência internacional, que, na realidade, não é problema afeto à competência mas à própria jurisdição: quando se diz que nenhum juiz brasileiro é competente para conhecer de determinada causa, não se está fazendo uma distribuição da jurisdição entre juízes, mas simplesmente afirmando que falta à autoridade brasileira em geral o próprio poder a ser exercido",2

\footnotetext{
${ }^{1}$ CINTRA, Antonio Carlos de Araujo; GRINOVER, Ada Pelegrini; DINAMARCO, Cândido Rangel. Teoria do Processo. São Paulo: Malheiros Editores, $27^{\text {a }}$ edição. et al, 2011, p. 251.

${ }^{2}$ Ibid, p. 252
} 
Assim, percebe-se que a jurisdição estatal é una e ilimitada sendo repartida em parcelas através de regras de competência. No Brasil, as regas de competência internacional são dividas em duas: absoluta (exclusiva), quando determina o monopólio jurisdicional estatal para si e, concorrente, quando concede eficácia no Brasil de julgado de outro Estado (arts. 88 e 89 do CPC, respectivamente) $)^{3}$.

As hipóteses contidas nos artigos supracitados não são cumulativas, uma vez que a competência será estabelecida de acordo com o evento de qualquer um dos fatos que vier a ocorrer. Esse entendimento é o do STJ que afirmou bastar a ocorrência de qualquer das hipóteses desses artigos para determinar-se a competência da autoridade judiciária brasileira.

Outra consideração é em relação à finalidade da norma de competência internacional, que se dá em dois casos. O primeiro caso trata do conhecimento originário de uma demanda que, em razão de sua pluriconexidade pode vir a ser apreciada pela Justiça de mais de um país. O segundo caso se refere ao momento de análise para fins de eficácia em território nacional, do reconhecimento de decisões estrangeiras e de laudos arbitrais que precisam ser homologadas no STJ, assim como o cumprimento de medidas judiciárias rogadas à pedido de juízes e tribunais estrangeiros ${ }^{4}$.

\footnotetext{
${ }^{3}$ Art. 88. É competente a autoridade judiciária brasileira quando:

I - o réu, qualquer que seja a sua nacionalidade, estiver domiciliado no Brasil;

II- no Brasil tiver de ser cumprida a obrigação;

III- a ação se originar de fato ocorrido ou de ato praticado no Brasil.

Parágrafo único. Para o fim, do disposto no $\mathrm{n}^{\circ} 1$, reputa-se domiciliada no Brasil a pessoa jurídica estrangeira que aqui tiver agência, filial ou sucursal.

Art. 89. Compete à autoridade judiciária brasileira, com exclusão de qualquer outra:

I - conhecer de ações relativas a imóveis situados no Brasil;

II - proceder a inventário e partilha de bens, situados no Brasil, ainda que o autor da herença seja estrangeiro e tenha residido fora do território nacional.

${ }^{4}$ ARAUJO, Nádia de. Direito Internacional Privado: Teoria e prática brasileira. Rio de Janeiro: Renovar, $3^{a}$ edição, 2006, 214 p.
} 
Assim, como mencionado, a competência internacional é determinada a partir de duas fases: primeiro, em observância dos artigos 88 e 89 do CPC o Poder Judiciário estabelece sua jurisdição respeitando os limites impostos, e depois, define as atribuições e delimitações da competência interna.

Quando a hipótese não estiver prevista em lei (arts. 88 e 89 ) surge dúvida acerca da competência jurisdicional brasileira. O entendimento não é unanime na doutrina nem na jurisprudência em relação às hipóteses não previstas. Alguns autores argumentam que seriam situações que não interessariam ao judiciário, detentor de atividade onerosa, sendo excluídas da Justiça brasileira. Seguindo a mesma linha, Antenor Madruga considera que tais situações implicariam na incompetência da Justiça brasileira que possuiria uma autolimitação: "o propósito das regras de competência internacional é fixar uma autolimitação à regra de jurisdição" 5 .

No entanto, Marcelo de Nardi entende que "a competência dos juizes nacionais se estende a todos os casos que possam estar conectados ao Brasil, por qualquer razão, inclusive a eleição de foro" ${ }^{6}$, assim, havendo qualquer dado de fixação de competência o judiciário brasileiro deve reconhecer-se competente. Assim como para Barbosa Moreira, “(...) a prestação jurisdicional assinale-se - não é favor que se conceda ad libitum da autoridade judiciária brasileira: é dever que corresponde ao direito assegurado no inciso XXXV [CRFB]" ${ }^{7}$. Dessa maneira, pode-se entender que haveria situações em que seriam um contrassenso negar a jurisdição, v.g. jurisdição voluntária. Nesses casos onde existe uma lacuna da lei, a disposição legal que indica a competência interna deveria servir para

\footnotetext{
${ }^{5}$ FILHO, Antenor Pereira Madruga. A Renúncia à Imunidade de Jurisdição pelo Estado Brasileiro e o novo Direito da Imunidade de Jurisdição. Rio de Janeiro: Renovar, 2003, 90 p.

${ }^{6}$ NARDI, Marcelo de. A lei e o foro de eleição em contratos internacionais: uma visão brasileira, in RODAS, João Grandino (Coord), Contratos Internacionais, $3^{\text {a }}$ edição. São Paulo: Editora Revista dos Tribunais, 2002, $134 \mathrm{p}$.

${ }^{7}$ MOREIRA, José Carlos Barbosa. Garantia Constitucional do Direito à Jurisdição - Competência Internacional da Justiça Brasileira. Prova do Direito Estrangeiro". Revista Forense, Vol. 343, 1998 $278 \mathrm{p}$.
} 
determinar a competência internacional de modo a evitar a denegação da Justiça.

Não obstante, ressalta-se a possibilidade das partes poderem livremente escolher não aproveitar-se da Justiça estatal, seja ela nacional ou estrangeira sem que isto configure a denegação da Justiça. Isso ocorre quando no contrato firmado entre as partes existir uma cláusula compromissória - deslocando a competência judiciária para a arbitral. A Lei de Arbitragem (Lei 9307 de 1996) e o CPC (art. 267, VII) determinam que na presença de tal cláusula o juízo estatal é incompetente para julgar a causa, devendo extinguir o processo sem resolução do mérito.

No entanto, casos não previstos no art. 88 do CPC que versam sobre o direito da família são sujeitos a tratamento diferente dos casos envolvendo questões contratuais. Isto em razão da essência de ordem pública que integra questões familiares, diferente dos contratos que prezam pela autonomia da vontade das partes, que são regidos por outra essência. Dessa maneira, tratando-se de menores, residentes no Brasil, que sejam partes de uma ação de alimentos (natureza alimentar), mesmo não se enquadrando em uma das hipóteses do artigo 88 é possível que o juiz brasileiro se entenda competente em razão da proteção que o direito da família deve receber e também por poder usar a Convenção Interamericana - da qual o Brasil é signatário - que possibilita tanto o domicilio do devedor quanto do credor para obrigações alimentares já em vigor.

Note-se ainda, a existência nos países de Common Law a possibilidade de forum non conveniens. Este princípio se encontra na Convenção de Nova York e, basicamente, permite que um tribunal não conheça de uma demanda quando o foro escolhido pela parte autora seja particularmente inconveniente e 
quando um foro mais adequado exista ${ }^{8}$. A doutrina do forum non conveniens é considerada uma regra procedimental, tendo se tornado uma regra padrão nos processos dos países de Common Law, permitindo o não conhecimento da demanda levando em consideração a conveniência, equidade, economia processual e o poder inato do judiciário de se auto organizar. É, portanto, característico de países do Common Law, não sendo aplicável aos países de Civil Law. Aliás, a Convenção de Lugano 44/2001 de 22 de dezembro de 2001 estabelece um sistema para determinar a jurisdição das cortes nacionais, excluindo a possibilidade de aplicabilidade do forum non conveniens ${ }^{9}$.

No entanto, não conhecimento do Tribunal não impede o Autor de ajuizar a ação novamente em outro Tribunal.

\subsection{Competência Internacional Concorrente}

A competência concorrente refere-se aos casos em que tanto o Judiciário brasileiro é competente para conhecer e resolver uma demanda, como o Judiciário de outro Estado. Dessa maneira, a ação poderá ser ajuizada ou no Brasil ou em outro país. Isto posto, "não exclui a jurisdição de outros Estados, mas também não abdica de sua competência"10.

Sendo um caso de competência concorrente existe a possibilidade de se optar pela jurisdição de um ou outro país. Esse tipo de competência é justamente a prevista no artigo 88 do CPC. Portanto, configurando um dos pressupostos do dispositivo, o autor da ação poderá escolher entre a jurisdição nacional ou estrangeira. Em consequência, uma eventual sentença estrangeira

\footnotetext{
${ }^{8}$ Chapter 14: Selection of Arbitral Seat in International Arbitration. BORN, Gary B, International Commercial Arbitration, Second Edition (Kluwer Law International; Kluwer Law International 2014), 2015-2119 p.

${ }^{9}$ REYNES, Victor Bonnin. Forum non conveniens: A Hidden Ground to Refuse Enforcement of Arbitral Awards in the United States, Journal of International Arbitration, (Kluwer Law International; Kluwer Law International 2013, Volume 30, Issue 2), 165-175 p.

${ }^{10}$ ARAUJO, Nádia de. Direito Internacional Privado: Teoria e prática brasileira. Rio de Janeiro: Renovar, $3^{\text {a }}$ edição, 2006, 222 p.
} 
poderá ser homologada no STJ estando presentes os requisitos legais para tanto.

É importante ressaltar que a competência concorrente não se confunde com a lei aplicável ao caso. A primeira é de ordem processual e determina o local de resolução do litígio, a segunda diz respeito ao direito material aplicável ao caso, podendo diferir da lei do local competente para conhecer a ação. Destarte, a posição do STJ que afirma ser necessário ocorrer tão somente uma das hipóteses do artigo 88 para considerar-se competente a Justiça brasileira, não se importando com as possíveis implicações que isso possa vir a ter no exterior.

Por conseguinte, no caso concreto em que a competência seja concorrente e a ação proposta no exterior, é preciso ter a anuência do réu domiciliado em território brasileiro para dar continuidade à ação. A citação é feita espontaneamente ou por carta rogatória e a sentença será futuramente homologada no STJ para passar a ter efeitos no Brasil.

Ressalta-se que no direito internacional privado brasileiro não há litispendência, dessa forma, uma vez proposta ação no exterior simultânea a outra em território nacional, enquadrando-se na hipótese do artigo 88, ambas as jurisdições - estrangeira e nacional - poderão ser competentes e as ações poderão correr simultaneamente. $\mathrm{O}$ ajuizamento no exterior não acarretará na prorrogação de competência nem prevenirá o juiz brasileiro. Se o litígio for resolvido no Brasil e fizer coisa julgada a mesma ação que foi proposta no exterior não poderá ser homologada no STJ nem ter seus efeitos sentidos no Brasil em razão de a questão já ter sido resolvida.

Por fim, é importante abordar o tema dos efeitos da cláusula de eleição de foro em um contrato no qual a cláusula opta por um foro estrangeiro e um dos pressupostos do artigo 88 se faz presente, uma vez que a competência 
concorrente poderá fazer uso da Justiça nacional. A cláusula de eleição de foro é a "escolha de um foro para a propositura de futuras e possíveis demandas, celebradas mediante convenção entre dois ou mais sujeitos" (art.111, do CPC), ou seja, privilegia-se a autonomia e vontade das partes. No entanto, o entendimento atual para o STJ se mostra no sentido de compreender a competência internacional como norma imperativa - como se verá adiante - e dessa forma, algo na qual as partes não podem abrir mão por meio de uma cláusula contratual. Mesmo assim, pode-se dizer que, "essa posição do STJ parece não representar uma posição fechada da Corte (...) admitiu que a eleição do foro é válida, exceto quando a lide envolver interesses públicos",11.

\footnotetext{
${ }^{11}$ Ibid.. 228 p.
} 


\section{CAPÍTULO 2 SITUAÇÃO ATUAL DO ARTIGO 88 NO CÓDIGO DE PROCESSO CIVIL DE 1973}

\subsection{Teoria}

Como explicado na parte preliminar, o artigo 88 trata de competência concorrente, o que significa afirmar competência da Justiça brasileira para processar e julgar uma ação, sem excluir a possibilidade de que esta ação venha a ser, igualmente, processada e julgada por Justiça estrangeira. Restando a essa sentença estrangeira ser homologada pelo STJ para produzir efeitos em território nacional. Lembre-se que nos casos de competência deste artigo, ações podem ser propostas no Brasil e no exterior, uma vez que não ocorre o fenômeno da litispendência em sede internacional, não operando como exceção processual.

Frise-se que para o direito brasileiro, a nacionalidade da parte envolvida é "elemento totalmente irrelevante à determinação da competência, quer no âmbito internacional, quer no âmbito interno",12, uma vez que a lei brasileira faz uso de outras regras de conexão, como, por exemplo, de territorialidade. Dessa maneira, a jurisdição é restringida aos limites territoriais do país.

Além disso, existe também a garantia constitucional da inafastabilidade da jurisdição. Portanto, nacional ou estrangeiro, residente ou não, a Justiça brasileira fundamenta sua competência com base neste principio, conforme explicitado no artigo $5^{\circ}, \mathrm{XXXV}$, da CRFB que assegura os direitos fundamentais nele previstos a todos as pessoas, porquanto possui caráter universal. Assim, basta estar dentro do território brasileiro para que tais direitos e garantias sejam assegurados a todos. Do contrário iria contra a

\footnotetext{
${ }^{12}$ CARNEIRO, Athos Gusmão. Competência Internacional Concorrente. Artigo 88 do CPC e o foro de eleição. Revista Forense, vol. 352, 42-43 p.
} 
intenção do constituinte. A prestação jurisdicional prevista neste dispositivo da Constituição é tida como dever e o "descumprimento de tal dever- denegação de justiça-fere a constituição com gravidade igual, sejam quais forem a nacionalidade e a sede da pessoa (fisica ou jurídica) lesada". ${ }^{13}$

Como consequência, no momento em que alguma situação se enquadre nos termos do artigo 88 , a pesquisa a ser feita será a do órgão interno competente para conhecer a demanda.

No que diz respeito à possibilidade de cláusula de eleição de foro em contratos internacionais, vale lembrar que o contrato internacional é aquele que contém algum elemento de estraneidade. Isto é, ou partes de países diferentes, ou a execução do contrato em outro local que não aquele onde foi assinado, etc. Assim, a cláusula que elege o foro inserida num contrato internacional é a materialização da vontade das partes de escolher qual tribunal terá jurisdição sobre uma eventual lide decorrente do contrato.

A eleição de foro é um problema de natureza processual internacional e a não inserção dessa cláusula em contrato, ou mesmo o fato de não existir contrato escrito não implica necessariamente que uma das partes não estará sujeita à jurisdição de tribunais de outros países. Assim sendo, a inclusão de tal cláusula ameniza o risco de "captura" por uma jurisdição que possa ser considerada indesejada por uma das partes. Como, por exemplo, "a norte americana (devido aos seus altos custos, elevados honorários profissionais, punitive damages, etc.) ou mesmo a europeia (pelo menos em casos de contratos cíveis e empresariais). $" 14$, por mais que a doutrina e a jurisprudência oscilem quando tratam desta matéria.

\footnotetext{
${ }^{13}$ MORREIRA José Carlos Barbosa. Competência Internacional - prova de direito estrangeiro - ônus de quem o alega. Revista do Processo, vol. 91, 1998, 221 p.

${ }^{14}$ TIMM, Luciano Benetti. A cláusula de eleição de foro versus a cláusula arbitral em contratos internacionais: qual é a melhor opção para a solução entre as partes? Revista de Arbitragem e Mediação, vol. 10, 2006, 23 p.
} 
A jurisdição estadunidense em litígios internacionais, justamente em razão dos punitive damages faz com que muitas vezes as cortes americanas sejam vistas como atraentes, pois podem ser acionadas por estrangeiros não residentes, embora sejam também consideradas problemáticas. Os citados punitive damages implicam em indenizações milionárias. Esse fenômeno de escolher um foro neutro, sem ter necessariamente uma regra de conexão como lugar se denomina forum shopping; "Trata-se de demandas que poderiam ser ajuizadas em outros locais, mas que a parte demandante prefere arriscar nos Estados Unidos." 15.

Para combater essa lógica, os tribunais americanos criaram instrumentos para encontrar um tipo de equilíbrio entre o interesse público e o privado. Em contraposição ao forum shopping existe o forum non conveniens. Assim, ao analisar-se uma cláusula que preveja o local do foro os EUA, analisa-se também, se há algum tipo de submissão à outra jurisdição ou se existiria algum outro tribunal onde fosse mais adequado resolver a lide.

Já o modelo europeu de jurisdição internacional, como base do brasileiro, determina como regra geral de jurisdição o domicílio, sendo regido pelo Regulamento de Bruxelas de 1968, que foi aperfeiçoado e substituído pela Nova Convenção de Lugano ou Lugano II (assinada em 2007 pela União Europeia, Dinamarca Islândia, Noruega e Suiça) ${ }^{16}$. Essa convenção também

\footnotetext{
${ }^{15}$ Ibid, 25-26 p.

${ }^{16} \mathrm{~A}$ diferença entre Regulamento e Convenção é que o primeiro é "Um tanto quanto rara, essa terminologia não apresenta uma definição muito nítida (...) É também usada (mas sem a roupagem de tratados) para designar as normas gestoras de alguns organismos ou tribunais internacionais”, o segundo: "começou a ser empregada no sentido atual a partir da proliferação dos congressos $e$ conferências internacionais, nos quais matérias da maior relevância para a sociedade internacional passaram a ser frequentemente debatidas, dando à luz atos internacionais da vontade uniforme das partes em assunto de interesse geral. A expressão convenção conota então aquele tipo de tratado solene (e multilateral) em que a vontade das partes não é propriamente divergente.". MAZZUOLI, Valerio Oliveira de. Curso de Direito Internacional Público. $7^{\text {a }}$ ed.. São Paulo: Revista dos Tribunais, 2013, 196 e 203 p.
} 
prevê regras para os não residentes serem processados fora de seu domicílio, e diferentemente do Brasil prevê a possibilidade de litispendência, ficando prevento o primeiro juízo onde foi ajuizado a demanda.

Voltando para o Brasil, como já mencionado, o artigo 88 determina a competência concorrente da Justiça brasileira o que pode, na prática, causar uma corrida para os locais onde a ação possa ser proposta, uma vez que somente com a homologação da sentença estrangeira pelo STJ é que o efeito da coisa julgada pode ser sentida no Brasil.

Dessa maneira, ainda que possível, embora não haja unanimidade, as regras do artigo 88 poderão ser afastadas quando houver a previsão no contrato internacional de cláusula de eleição de foro indicando local estrangeiro e configurando a submissão expressa e voluntária à jurisdição estrangeira.

Para esse possível afastamento, a redação da cláusula deve ser escrita e especificar o negócio jurídico por ela coberto. Pois que, além do STJ dispor de jurisprudência praticamente pacífica acerca da competência concorrente, existe igualmente jurisprudência no sentido de evitar tal cláusula em contratos de adesão, já que sua inclusão normalmente é para dificultar o acesso à Justiça, sendo considerada uma cláusula abusiva. Ademais, a cláusula não pode ferir a ordem pública, constituir fraude à lei e nem afastar foro inderrogável.

Alguns tribunais estaduais, como o TJRJ e o TJSP possuem a mesma jurisprudência do STJ de não admitir a exclusividade da cláusula de eleição de foro prevista em um contrato internacional, permitindo o julgamento da demanda ajuizada em sede doméstica mesmo havendo foro eleito no estrangeiro. Isto, em razão do poder da competência concorrente. Sua fundamentação está em que o particular não poderia estabelecer jurisdição própria, pois a jurisdição é função estatal, sendo os artigos que preveem a competência internacional de ordem pública, portanto, inderrogáveis. Relevam 
as cortes nacionais que em se tratando de direito disponível e de direito privado, o contrato serve como lei entre as partes, podendo ser regido pela autonomia das partes.

Para o José Carlos Barbosa Moreira "constitui perda de tempo demorar-se em elucubrações sobre, in casu, a Justiça nacional estaria ou não obrigada a conhecer da causa com base na convenção das partes, e consequentemente na opção, manifestada pela autora, de submeter-lhe o litígio. Esteja ou não esteja vinculada pela cláusula de eleição de foro inserta no contrato, é fora de dúvida que a nossa Justiça está vinculada pelo ordenamento em vigor no Brasil","17.

A posição do José Carlos Barbosa Moreira afirma a imperatividade da competência concorrente nacional. No entanto, embora mais escassos, existem alguns julgados do TJRS e do TJRJ que aceitam a exclusividade da eleição de foro $^{18}$. Esse posicionamento estaria de acordo com o direito processual internacional comparado e seria mais adequado aos contratos e litígios internacionais.

Além da necessidade da cláusula ser escrita, é preferível que ela opte por um foro conveniente para as partes o qual advenha de alguma regra de conexão. Isto porque parte da doutrina nacional acredita que a determinação de um tribunal "neutro" não é válida. Por essa razão, a doutrina defende também que os tribunais brasileiros não devam julgar casos que não caiam nas hipóteses do artigo 88 (nem do artigo 89).

Apesar desse entendimento doutrinário, pode-se dizer que ele é equivocado e ultrapassado. Existem autores latino-americanos que arguem que a mera expressão de vontade das partes por um foro neutro configura elemento suficiente para tornar tal foro válido e conveniente. Os Estados Unidos também

\footnotetext{
${ }^{17}$ MORREIRA, José Carlos Barbosa. Competência Internacional - prova de direito estrangeiro onus de quem o alega. Revista do Processo, v. 91, 1998, 221 p. Revista do Tribunais online, 15 p.

${ }^{18}$ Agravo de Instrumento $n^{\circ} 70.005 .228 .440,19^{a}$ Câmara Cível, TJRS, Min. Rel. Luís Augusto Coelho Braga, julgado em 08.04.2003; Apelação Cível n ${ }^{\circ}$ 5097/94, de 06.12.1994; Agravo de Instrumento ${ }^{\circ}$ 7.195/2001. TIMM, Luciano Benetti. A cláusula de eleição de foro versus a cláusula arbitral em contratos internacionais: qual é a melhor opção para a solução entre as partes? Revista de Arbitragem e Mediação, vol. 10, 2006, 27-30 p.
} 
se admitem como fórum conveniente por ser indicado pelas partes, mesmo não havendo relação jurídica entre as partes ou o contrato.

Há que se verificar, ainda, se existem filiais no Brasil da empresa estrangeira que celebrou o contrato internacional com foro estrangeiro, uma vez que a presença indireta em território nacional para atrair a jurisdição nacional pela "teoria da aparência", invocando-se o artigo 88.

Por fim, é importante saber se a decisão do tribunal estrangeiro será homologável e exequível no país onde os ativos se encontram. Sendo de importantíssimo relevo redigir uma cláusula clara.

Assim, a discussão da competência concorrente com base no artigo 88 determina que os tribunais brasileiros podem, eventualmente - e na maior parte das vezes o fazem - não aceitar a autonomia da vontade das partes para a escolha do foro, o que gera grande incerteza e insegurança nas negociações internacionais, podendo enfraquecer a posição negocial brasileira.

\subsection{Eleição de Foro e Casos}

É importante analisar a orientação dos tribunais em relação à interpretação que é dada ao artigo 88 do CPC no que diz respeito à possibilidade de eleição de foro que eleja outro local para a resolução do conflito, mesmo estando presentes um dos pressupostos do artigo. Isto é, se se entende a competência concorrente como imperativa ou como dispensa da jurisdição estatal.

Para tanto foram estudados alguns julgados mais recentes do Supremo Tribunal Federal (STJ), do Tribunal de Justiça do Rio Grande do Sul (TJRS), do Tribunal de Justiça do Rio de Janeiro (TJRJ) e do Tribunal de Justiça de São Paulo (TJSP) que abordam esse tema. 
O tema chegou poucas vezes ao STJ, porém, as decisões exaradas reiteraram, via de regra, o mesmo entendimento. Como, por exemplo, no REsp $n^{\circ}$ 251.438- RJ (2000/0024821-5). O caso envolvia a Braspetro Oil Services Company - Brasoil que, em razão de licitação internacional vencida pelo consórcio de as empresas "Indústrias Verolme/Ishibrás S.S- IVI", assinou contrato que tinha como objeto a execução de serviços para a conversão de um navio petroleiro em unidade flutuante de tratamento, armazenamento e escoamento de óleo e gás. Como garantia da execução do ajuste, a "American Home Assurance Company" e a "United States Fidelity and Guaranty Company" emitiram um performance bond. Alegando que tal consórcio descumprira seus deveres, a Brasoil ajuizou perante a Justiça brasileira uma ação ordinária de perdas e danos c/c cobrança da apólice de seguro- garantia de execuções das obrigações contratuais ("performance bond"), contra as empresas.

Na primeira instância a ação foi extinta sem julgamento de mérito nos termos do art. 267, IV do CPC em relação às co-rés American Home e United States Fidelity por falta de jurisdição brasileira, tendo como fundamentos os seguintes pontos:

“a) na relação jurídica entre a Brasoil, American Home e United Slates Fidelity, as envolvidas são empresas estrangeiras, domiciliadas no exterior; b) o 'performance bond' foi emitido nos EUA e o pagamento do eventualmente devido seria em dólares norte-americanos, também no exterior; c) o 'performance bond' possui cláusula eletiva de foro (Corte Distrital de Nova York); d) o mencionado 'performance bond' não é acessório do contrato de construção." (grifos meus).

A jurisdição brasileira foi restabelecida por meio de agravo de instrumento pela Décima Sétima Câmara do Tribunal do Rio de Janeiro. Insatisfeitas, as co-rés interpuseram recurso especial e, no que tange à competência internacional, alegaram o seguinte: 
“contrariedade aos arts. 88, I, II e III, 100, IV, 292, \$1 , II do CPC: 12 da LICC e 950 do Código Civil, em virtude da ausência de jurisdição brasileira. Sustentaram, neste tópico, que: I- tratando-se de competência concorrente da autoridade judiciária brasileira, é suscetivel ela de ser afastada pela vontade das partes; II- a existência de filial da co-ré American Home no país é irrelevante, seja porque isto não determina automaticamente a competência obrigatória da Justiça nacional, seja porque nenhum dos atos relacionados à presente causa foram praticadas na aludida filial (...) IV-o 'performance bond' foi emitido em Nova York, onde o prêmio foi pago; $V$ - o eventual pagamento elas garantidoras teria lugar nos EUA com credito em dólares norte-americanos, pelo que a obrigação deveria ser cumprida nos EUA, onde a moeda tem curso forçada (...).".

O Ministro Relator do caso foi o Barros Monteiro que anunciou como o ponto crucial da controvérsia saber se o juiz brasileiro tinha competência para julgar o litígio internacional. Dentre os argumentos trazidos pelo Ministro, foi enfatizada a possibilidade de ajuizamento tanto no exterior quanto em território nacional em se tratando de competência concorrente, uma vez que qualquer convenção entre as partes não teria força suficiente para servir de obstáculo de ingressos da ação nos tribunais brasileiros e de que o foro de eleição estipulado no performance bond constituía disposição facultativa.

O Ministro concluiu por afirmar que como a obrigação principal teria que ser cumprida no Brasil, materializar-se-ia a hipótese do art. 88, II do CPC, o que, portanto, tornaria cabível a jurisdição nacional. Dessa maneira, os motivos abordados na primeira instância seriam irrelevantes e a competência do juiz brasileiro não poderia simplesmente ser afastada pela vontade das partes ao estabelecerem cláusula de eleição de foro, uma vez que as normas de competência internacional seriam de ordem pública.

O Ministro salientou, ademais, que o Tribunal de Justiça de São Paulo já teria decidido no sentido de determinar que a cláusula de eleição de foro em hipótese de competência internacional concorrente não teria o poder de afastar 
a jurisdição brasileira por violação de princípio constitucional: "válida a eleição de foro estrangeiro, permanece a concorrência, isto é, a autoridade brasileira não estará impedida de apreciar a matéria: terá competência (ou melhor, jurisdição).” (Revista dos Tribunais, vol. 632. pág. 84).

Final parecido teve o REsp n ${ }^{\circ} 1168547 /$ RJ (2007/0252908-3) no qual o Recurso, oriundo de uma ação de indenização por uso indevido de imagem, tendo como Autora uma brasileira e a Ré uma empresa espanhola tinha como questão fundamental decidir se a Autora, que tinha domicílio brasileiro, poderia fazer uso da Justiça nacional em caso de contrato de prestação de serviço como dançarina e assistente de direção em show típico brasileiro que fora assinado e executado na Espanha e que continha cláusula de eleição de foro na Espanha.

A Autora alegava que mesmo após o término do contrato a empresa espanhola mantivera em seu sítio eletrônico montagens de imagens suas que teriam sido recortadas de várias fotografias de shows nos quais havia trabalhado e que haveria uma vedação expressa para a utilização de imagens sem prévia autorização da artista no contrato que fora assinado entre as partes.

Por sua vez, a Ré, uma vez citada, alegou a incompetência da Justiça brasileira como preliminar e a ação foi julgada extinta sem resolução de mérito na primeira instância.

A Autora, inconformada, apelou da sentença que, na segunda instância, foi modificada entendendo ser competente a Justiça brasileira com base no art. 88, III do CPC. Ou seja, apesar do sítio eletrônico ser espanhol este poderia ser acessado e mostrado em computadores instalados no Brasil e, portanto, as imagens também. Dessa forma, poder-se-ia considerar o ato como praticado no Brasil. 
A Ré, nas Razões ao Recurso Especial sustentou que, apesar da possibilidade de acesso do sítio eletrônico espanhol em território brasileiro, a Justiça espanhola era a competente, uma vez que:

“a) o contrato de trabalho firmado entre as partes se deu na Espanha, sob a égide da legislação espanhola (R.D. 1435/85);

b) a empresa contratante é espanhola e não possui sede ou filial no Brasil;

c) o sítio eletrônico $w w w$.brasilcarnaval2000.com, onde as reclamadas imagens/fotografias da autora estão veiculadas, é espanhol;

d) os shows onde as fotografias/imagens foram obtidas realizaram-se na Espanha e em outros países da Europa;

e) se a causa de pedir da indenização é o uso indevido da imagem da autora em sítio eletrônico da empresa recorrente, imprescindível se faz a análise do contrato;

f) o fato de um internauta poder acessar do Brasil o conteúdo de um sítio estrangeiro não tem o condão de fixar a competência da jurisdição brasileira.

(...) Sustenta que no contrato firmado entre as partes foi fixado como foro de eleição a cidade de Málaga, na Espanha, para a solução de quaisquer controvérsia oriundas do contrato de prestação de serviços."

Expostos os argumentos, o Relator, Min. Luis Felipe Salomão, enfrentou-os reconhecendo primeiramente a dificuldade das questões que envolvem a internet e o ciberespaço uma vez que não há regulamentação estatal acerca do impacto da internet sobre o direito e as relações jurídicosociais.

No entanto, afirmou que a alegação da empresa espanhola de não ter sede ou filial no Brasil não a impediria de ser processada no Brasil conforme declara o CPC em seus art. 100, IV, alíneas 'b' e 'c' c/c art. 12, VII e VIII. Tampouco afastaria a jurisdição brasileira a circunstância de o sítio eletrônico ser espanhol, já que o seu acesso se dá pela rede mundial.

Em relação à propositura da ação indenizatória por danos materiais e morais, esclareceu o Ministro o entendimento preponderante da regra específica do art. 100, V, alínea 'a' do CPC que determina que a demanda pode ser ajuizada no foro do local onde ocorreu o ato/fato apesar de a Ré ser pessoa jurídica com sede em lugar diverso. 
Salientou o Ministro que a questão primordial era avaliar se a cláusula de eleição de foro, prevista no contrato entre as partes que estabelecia a cidade de Málaga na Espanha como eventual foro competente para a solução de conflitos, era capaz de afastar a jurisdição brasileira tendo a Autora domicílio no Brasil.

Para tal, invocou as hipóteses da jurisdição concorrente (cumulativa) do Poder Judiciário Brasileiro do art. 88 do CPC, e o princípio da inafastabilidade da jurisdição que confere ao Estado a obrigação de resolver as lides que lhe são oferecidas como forma de garantir a paz social. À vista disso, arguiu que embora a cláusula de eleição de foro no exterior seja admitida no sistema jurídico brasileiro, ela não impede a propositura de ação no Brasil em se tratando de competência concorrente. O Ministro concluiu afirmando que:

"quando a alegada atividade ilícita tiver sido praticada pela Internet, independentemente do foro previsto no contrato de prestação de serviço, ainda que no exterior, é competente a autoridade judiciária brasileira caso acionada para dirimir o conflito, pois aqui também houve o acesso ao sítio eletrônico onde a informação foi veiculada, interpretando-se como ato praticado no Brasil, aplicandose à hipótese o disposto no artigo 88, III, do CPC.”.

Em vista da argumentação feita pelo Ministro Relator, a Turma, por unanimidade, negou provimento ao recurso especial. Isto é, reconheceu-se a imperatividade da Justiça brasileira em se tratando de competência concorrente.

E assim, mais uma vez, a Quarta Turma do STJ, por unanimidade, não conheceu do recurso.

Percebe-se que, como reiterado na preliminar, o STJ firma a posição de que é necessário ocorrer tão somente uma das hipóteses do artigo 88 para configurar-se a competência concorrente e considerar-se competente a Justiça 
brasileira, consolidando assim o entendimento de o art. 88 ser norma imperativa.

O Tribunal de Justiça do Rio Grande do Sul também entende que, em se tratando de competência concorrente brasileira, a cláusula de eleição de foro que elege foro estrangeiro perde aplicabilidade, e então, por mais que haja manifestação de vontade das partes em sentido diverso, a Justiça brasileira tem o poder de invocar sua jurisdição e proceder com o julgamento da ação, já que se faz presente uma das hipóteses da competência cumulativa.

É o que se entende pela análise dos julgados mais recentes a respeito do tema do Tribunal. Tome-se, como exemplo o Agravo de Instrumento $\mathrm{n}^{\circ}$ $700.300 .3514^{19}$ :

COMPETENNCIA INTERNACIONAL. JURISDIÇÃO CONCORRENTE. FORO DE ELEIÇÃO. ILÍCITO CONTRATUAL. Tratando-se de competência relativa, ainda que o contrato tenha sido firmado fora do Brasil, com adoção de foro de eleição, quando em detrimento da parte mais fraca, é de se manter o foro local como o competente, mormente quando os atos lesivos foram aqui praticados e os réus, com exceção de um, têm seus domicílios no país e o sediado fora do Brasil, tem aqui representante legal. Aplicação das regras dos arts. 88 e 94, § 40, do CPC. (grifos meus).

O julgado acima recebeu a mesma interpretação que o Agravo de Instrumento $\mathrm{n}^{\circ} 700.239 .687-04^{20}$ oriundo de uma ação que versava sobre um incidente de exceção de incompetência. $\mathrm{O}$ foro eleito pelas partes para dirimir quaisquer controvérsias era a cidade de Marselha, na França, porém a ação havia sido ajuizada na comarca de Porto Alegre. No entanto, não sendo cumulativos os pressupostos da competência concorrente, a Justiça brasileira pode determinar-se competente em qualquer uma das hipóteses dos incisos do artigo. No caso, o réu era domiciliado no Brasil. Ademais, havia sede da agravante, que pediu a remessa para a França em território brasileiro, no Rio de

\footnotetext{
${ }^{19}$ Agravo de Instrumento No 70003003514, Quinta Câmara Cível, Tribunal de Justiça do RS, Relator: Marco Aurélio dos Santos Caminha, Julgado em 13/09/2001

${ }^{20}$ Agravo de Instrumento No 70023968704, Décima Segunda Câmara Cível, Tribunal de Justiça do RS, Relator: Judith dos Santos Mottecy, Julgado em 05/06/2008
} 
Janeiro. Ultimou-se, então, que a cláusula de eleição de foro não poderia afastar a competência da Justiça brasileira.

O Tribunal de Justiça do Rio de Janeiro, assim como o TJRS, tende a seguir o entendimento adotado pelo STJ no sentido de que a cláusula de eleição de foro não tem o condão de afastar a jurisdição brasileira quando esta for invocada por uma das partes, por mais que se tenha elegido foro diferente. A competência relativa e concorrente do Estado brasileiro tem sido interpretada de forma a afastar a eleição de foro e prosseguir com o julgamento das demandas.

É o que se percebe, também, nos julgados mais recentes do TJRJ atinente a esse tema. Consideremos a Apelação 0160679-93.2005.8.19.0001 $(2007.001 .34305)^{21}$. A ação referia-se a uma rescisão contratual no qual o contrato havia sido celebrado nos Estados Unidos com cláusula de eleição de foro no exterior, no entanto o cumprimento da obrigação ocorreu, ou deveria ocorrer, no Brasil. Assim, entendeu-se que a competência concorrente da Justiça brasileira não poderia ser colocada à disposição da vontade das partes, por se tratar de norma baseada na soberania nacional.

A mesma lógica fora invocada no julgamento da Apelação nº 0325793 06.2013.8.19.0001 ${ }^{22}$. No caso, a controvérsia surgiu de um contrato de representação empresarial internacional no qual as partes estabeleceram que a Justiça italiana seria a competente para resolver eventuais conflitos oriundos do contrato. Todavia, o juiz estabeleceu que, por mais que a cláusula de eleição de foro fosse uma possibilidade de mitigação da competência territorial, no caso concreto, como a obrigação deveria ser cumprida no Brasil, a cláusula de

\footnotetext{
${ }^{21}$ Apelação0160679-93.2005.8.19.0001 (2007.001.34305),Des. Luiz Fernando de Carvalho, 3a Câmara Cível, TJRJ, DJ 28/07/2009

${ }^{22}$ Apelação 0325793-06.2013.8.19.0001, Des. Rel. Claudio Dell’Orto, $18^{a}$ Câmara Cível do TJRJ, DJ 26/09/2014
} 
eleição de foro estrangeiro não afastava a competência concorrente brasileira em razão do artigo 88, II, do CPC.

Em um julgado interessante do TJRJ, do Agravo de Instrumento $\mathrm{n}^{\circ}$ 0005639-53.2007.8.19.0000 (2007.002.02478) ${ }^{23}$, a competência jurisdicional brasileira foi afastada, mesmo sendo caso de competência concorrente, porque a lide já fora julgada no exterior, aonde havia eleição de foro para tal. Portanto, mesmo tendo uma das partes sede no Brasil e não havendo litispendência em causas internacionais, por entender que a controvérsia já fora resolvida mesmo que no exterior - foi rejeitada a competência brasileira.

Por fim, o Tribunal de Justiça de São Paulo segue a jurisprudência do STJ ao reputar-se competente a Justiça brasileira na presença de um ou mais incisos do artigo 88. Assim, as cláusulas de eleição de foro que optaram por Justiça estrangeira acabaram sendo desconsideradas e o julgamento das ações continuou correndo no Brasil.

É o que se extrai do julgamento da Apelação 0219096-33.2008.8.26.0100²4, como o réu era pessoa jurídica com sede no Brasil e como o objeto do contrato foi firmado no Brasil, preencherem-se os requisitos do art. 88 do $\mathrm{CPC}$ e novamente, entendeu-se que a cláusula de eleição de foro, que elege um juízo estrangeiro como competente, não afastava a jurisdição brasileira.

O mesmo ocorreu no julgamento do Agravo de Instrumento $\mathrm{n}^{\circ} 2072302-$ 42.2013.8.26.0000 25 em que mesmo havendo cláusula de eleição de foro em Madri, Espanha, como a obrigação teria que ser cumprida no Brasil, rejeitou-se a exceção de incompetência da Justiça brasileira.

\footnotetext{
${ }^{23}$ Agravo de Instrumento 0005639-53.2007.8.19.0000 (2007.002.02478), Des. Ricardo Rodrigues Cardozo, 15a Câmara Cível, TJRJ, DJ 27/03/2007

${ }^{24}$ Apelação 0219096-33.2008.8.26.0100, Rel. Rebello Pinho, 20a Câmara de Direito Privado, TJSP, DJ 05/08/2013

${ }^{25}$ Agravo de Instrumento 2072302-42.2013.8.26.0000, Rel. Teixeira Leite, 1a Câmara Reservada de Direito Empresarial, TJSP, DJ 03/04/2014
} 
Finalmente, no julgamento da Apelação 0043542-60.2003.8.26.0100 ${ }^{26}$, proveniente de uma ação indenizatória entre uma empresa multinacional e sua subsidiária brasileira, a qual envolvia um contrato de distribuição comercial com foro de eleição em jurisdição estrangeira. Novamente, em razão da execução do contrato ser em território brasileiro, aplicou-se a imperatividade da competência concorrente.

Pela análise dos casos citados se percebe que a jurisprudência dos tribunais segue a mesma linha do STJ e considera que a competência relativa e concorrente da Justiça brasileira, quando presente algum dos pressupostos do artigo 88, tem força imperativa. Assim, por mais que seja possível elaborar uma cláusula que determine foro no exterior para resolver futuras controvérsias, essa cláusula tenderá a ser desconsiderada na hipótese de:

(i) o réu ter domicílio no Brasil, independente de sua nacionalidade;

(ii) o cumprimento da obrigação for no Brasil;

(iii) a ação se originar de fato ocorrido ou de ato praticado no Brasil.

Pode-se concluir que, no que tange a contratos internacionais, a cláusula de eleição de foro, que privilegia a autonomia da vontade das partes, não possui a força necessária para afastar a competência concorrente da Justiça brasileira.

\footnotetext{
${ }^{26}$ Apelação/ Duplicata 0043542-60.2003.8.26.0100, Rel. Itamar Gaino, $21{ }^{\text {a }}$ Câmara de Direito Privado, TJSP, DJ 19/05/2014
} 


\section{CAPÍTULO 3 ARTIGO 25 NO NOVO CÓDIGO DE PROCESSO CIVIL}

\subsection{Convenção de Haia sobre acordo de eleição de foro de 2005}

\subsubsection{Surgimento}

A Conferência Permanente de Direito Internacional Privado (Conferência de Haia) é sediada na Haia e tem como objetivo a uniformização das regras de direito internacional privado num mundo cada vez mais globalizado a fim de garantir mais segurança jurídica e previsibilidade nas relações jurídicas internacionais. O Brasil promulgou o Estatuto da Conferência de Haia por meio do Decreto 3.832/ 2001 e quando o texto do Estatuto foi emendado, o Brasil promulgou o Decreto 7156/ 2010 que tratava das emendas feitas. No que tange à participação do Brasil, o país aderiu à Conferência tendo somente ratificado, através do Decreto 3.087/ 1999, a convenção relativa à Proteção das Crianças e à Cooperação em matéria de Adoção Internacional (25.03.1993) ${ }^{27}$.

Em 2005, durante a vigésima Sessão da Conferencia da Haia, foi finalizada a Convenção de Haia sobre acordos de eleição de foro, a qual não somente procurou conferir previsibilidade em questão de jurisdição internacional, mas assegurar igualdade de condições à cláusula de escolha de foro com relação a cláusula compromissória, privilegiando o princípio da autonomia da vontade.

A Convenção de Nova York sobre Arbitragem Internacional (Decreto 4.311/ 2002) institui condições de segurança para a execução de laudos arbitrais estrangeiros garantindo segurança jurídica para quem adere à cláusula compromissória e participa de uma arbitragem internacional. Por seu lado, a

\footnotetext{
${ }^{27}$ Disponível em <http://www.sdh.gov.br/assuntos/adocao-e-sequestro-internacional/legislacao-epublicacoes/a-conferencia-de-haia-de-direito-internacional-privado-a-participacao-do-brasil>, p. 492493 acesso em 15.03.2015 às 14:56
} 
Convenção de Haia sobre acordos de eleição de foro (Convenção) visa conferir segurança jurídica similar aos optantes da Justiça estatal que recebem os da cláusula arbitral. Funciona, portanto, como uma alternativa judicial à via arbitral em contratos internacionais.

Os trabalhos para o estabelecimento da Convenção iniciaram-se em 1992 como proposta para o regulamento de todas as questões concernentes à jurisdição internacional. As negociações tiveram inicio em 1996, sendo interrompidas em 2001 e retomadas em $2002^{28}$. A Convenção foi elaborada por uma comissão especial nomeada pelo Secretariado da Conferência, tendo como foco único a cláusula de eleição de foro em contratos comerciais internacionais, denominados de B2B (business to business) ${ }^{29}$, com fito de incentivar o crescimento do comércio internacional. Por isso, ficaram excluídos da Convenção os contratos que versam, por exemplo, sobre o direito do consumidor ou direito da família - esses acabam envolvendo questões relacionadas à ordem pública e direitos indisponíveis, matérias que fogem da esfera da autonomia das partes. No entanto, até o momento os EUA, a União Europeia, a Singapura e o México assinaram a Convenção, tendo somente o ultimo ratificado. Porém, a União Europeia, nos dias 4 e 5 de dezembro de 2014 decidiu aprovar a Convenção e completou o processo interno de aprovação com o depósito do instrumento de ratificação ${ }^{30}$.

\footnotetext{
28 "Os trabalhos em prol desta convenção foram longos e começaram em 1992, a partir de uma proposta americana, em que se pretendia regulamentar todas as questões relativas à jurisdição internacional. As negociações começaram em 1996, mas foram interrompidas, durante a conferência diplomática de 2001, por ser a proposta final por demais ambiciosa para ser adotada. Em 2002, as negociações foram retomadas, agora com um campo bem menor, cuidando tão somente, de escolha de foro em contratos internacionais entre partes profissionais (B2B)". ARAUJO, Nádia de; VARGAS, Daniela. A Conferência de Haia de Direito Internacional Privado: Reaproximação do Brasil e análise das convenções processuais. Revista de Arbitragem e Mediação, vol. 35, 2012, 207-208 p.

${ }^{29}$ ARAUJO, Nádia de. Convenção de Haia sobre escolha de foro e o Brasil: necessidade de sua adoção. Revista Brasileira de Arbitragem, vol. 18, 2008, 29 p.

${ }^{30}$ Disponível em <http://www.hcch.net/index_en.php?act=events.details\&year=2014\&varevent=389> acesso em 09.05.2015 às $17 \mathrm{~h} 06$
} 
Não obstante a cláusula ter aparência simples, esta mesma foi vastamente discutida, por existir divergência sobre a necessidade de a cláusula ser explicitamente exclusiva, visto que em alguns sistemas jurídicos a inserção da cláusula já denota o seu caráter exclusivo, enquanto que em outros a exclusividade deve ser expressa ${ }^{31}$.

A Convenção limitou o seu campo de atuação com base em três regras: (i) só pode ser aplicada em casos internacionais, cuja definição se encontra no inciso 2; (ii) necessidade de cláusula específica e expressa sobre o foro eleito, caracterizando-o como exclusivo; (iii) limitação da matéria, que só pode ser civil ou comercial ${ }^{32}$.

\subsubsection{Características}

No primeiro item, como na cláusula arbitral, a Convenção tratou de atribuir caráter autônomo à cláusula de eleição de foro. Por conseguinte, a validade da cláusula é analisada de forma independente do contrato na qual é inserida de tal modo que a invalidade ou qualquer nulidade que possa atingir o contrato não necessariamente prejudicará a cláusula. Isto enfatiza a autonomia da vontade das partes contratantes.

Outro caráter da cláusula é sua exclusividade. É importante em relação a litispendência internacional, pois somente o foro eleito no contrato terá jurisdição para resolver os litígios dele oriundos. Significa dizer que, caso uma ação seja ajuizada em local que não seja o foro eleito entre estados signatários, esta deverá ser extinta sem julgamento de mérito em razão de incompetência do juízo. Esse caráter também impede que uma parte invoque a doutrina do

\footnotetext{
${ }^{31}$ ARAUJO, Nádia de; VARGAS, Daniela. Conferência de Haia de Direito Internacional Privado: Reaproximação do Brasil e análise das Convenções Processuais. Revista de Arbitragem e Mediação, vol. 35, 2012, 208 p.

32 ARAUJO, Nádia de; GAMA, Lauro Jr.; VARGAS, Daniela. Temas de Direito Internacional Privado no Projeto de Novo Código de Processo Civil. Revista de Arbitragem e Mediação, vol. 28, 2011, $151 \mathrm{p}$.
} 
forum non conveniens com o intuito de prevenir que o réu alegue isto como forma de se livrar da ação contra ele. A invocação do forum non conveniens teria o condão de enfraquecer as cláusulas de eleição de foro e por isso, optouse por não permitir a sua aplicabilidade na Convenção.

A segunda regra trata da ação que é proposta em um tribunal que não tenha sido o escolhido pelas partes, ou seja, um tribunal estranho à vontade das partes. Caso o tribunal eleito pelas partes (porém, não onde corre a ação) seja o de um país signatário da Convenção, o tribunal aonde foi ajuizada a ação deve renunciar de fazer o julgamento, mesmo quando sua lei interna reconhecesse sua competência em razão da Convenção. Assim, se uma ação foi iniciada em um tribunal, mas outro tribunal foi o escolhido pelas partes sendo ele de um país signatário da Convenção, o tribunal aonde a ação foi iniciada deve se abster de aceitar a jurisdição, respeitando o acordo internacional concretizado pela Convenção.

A terceira regra diz respeito ao tribunal aonde a sentença será executada. "A Convenção só faz sentido quando a decisão necessitar de reconhecimento em outro país, porque a execução no país que aceitou a jurisdição é parte da aceitaçãoo",33. Assim como na Convenção de Nova York, a revisão de mérito no tribunal onde a sentença será executada é proibida, pois o tribunal que executará a sentença não pode servir como jurisdição recursal. Portanto, a Convenção formulou regras para evitar que a execução da sentença fosse inviabilizada sendo as possibilidades de recusa limitadas e de acordo com as regras internas brasileiras, assimilando-se com as regras de homologação de sentença estrangeira.

O segundo capítulo da Convenção trata de regras de jurisdição que devem ser adotadas pelas cortes eleitas. Primeiramente, sendo o país signatário

\footnotetext{
${ }^{33}$ ARAUJO, Nádia de. Convenção de Haia sobre escolha de foro e o Brasil: necessidade de sua adoção. Revista Brasileira de Arbitragem, vol. 5, 2008, 34 p.
} 
da Convenção o seu tribunal, caso eleito, não pode deixar de julgar uma demanda - a não ser que recaia sobre uma exceção prevista na Convenção, casos verdadeiramente restritos, como por exemplo, a incapacidade da parte que levaria à invalidade da cláusula. Assim, o Tribunal não pode simplesmente dispensar o julgamento da ação.

Em razão da incerteza atual da matéria, por não haver uniformidade nas diversas jurisdições acerca da aplicabilidade da cláusula de escolha de foro, a cláusula arbitral tem sido mais utilizado nos contratos internacionais ao invés da cláusula de eleição de foro. Em função disto, a Convenção objetiva dar mais certeza à matéria.

Como já abordado na primeira parte deste trabalho, a questão da competência internacional concorrente que abrange a questão da cláusula de eleição de foro é polêmica no direito brasileiro, havendo uma dissintonia entre doutrina e jurisprudência. A consequência disso é a insegurança jurídica ao se optar por tal cláusula. A Convenção, então, permite uniformizar a questão no plano internacional ao mesmo tempo em que confere tratamento isonômico entre às cláusulas de eleição de foro e arbitral, uma vez que a arbitragem é aceita sem maiores indagações e por sua previsibilidade e segurança jurídica tem ganhado mais espaço que a cláusula de eleição de foro ao longo dos anos. No entanto, é verdade que a Convenção ainda depende de ratificação pelos países signatários para realmente concretizar seu objetivo.

A Convenção, portanto, fundamentalmente objetivou a normatização de uma prática amplamente aceita no plano internacional, com a finalidade de prevenir possíveis instaurações de litígios em diversos países, em razão desses países serem competentes simultaneamente. Tendo isto em vista, buscou eliminar a prática de fórum shopping que pode ter grande influência na hora da contratação, pois eventualmente pode afetar o seu custo. 
É importante ressaltar a incoerência entre o condão vinculativo entre as cláusulas arbitral e de eleição de foro. Enquanto a cláusula arbitral comporta aceitação que afasta a jurisdição estatal que seria competente caso não houvesse tal cláusula no contrato, a de eleição de foro ainda não necessariamente vincula o tribunal que pode ser concorrentemente competente, assim, mesmo havendo a cláusula, esta pode acabar por ser desconsiderada, não possuindo o condão vinculativo da cláusula arbitral. No entanto, por mais que a arbitragem seja uma forma de solução de controvérsia efetiva e importante, ela nem sempre é a mais adequada para resolver determinadas tipos de controvérsias - daí a necessidade de estabelecimento de patamares similares entre as cláusulas no plano internacional.

Percebe-se, então, que uma das razões da Convenção foi a de garantir segurança à cláusula de eleição de foro entre os países signatários, uma vez que o seu reconhecimento e força vinculativa passariam a ser respeitados. Existindo, essencialmente, a vontade de equiparar benefícios à resolução de conflitos estatais àqueles resolvidos por arbitragem internacional.

Apesar de a Convenção de Haia ser de 2005 e o Brasil ainda não ser signatário, o país tem mostrado interesse na mesma. Isto porque tem participado de atividades da Conferência da Haia para o Direito Privado, como, por exemplo, o Seminário promovido pela Conferência de Haia em conjunto com o Ministério da Justiça, na condição de representante da Presidência Protempore do Mercosul, realizada em Brasília no ano de 2010, assim como na área acadêmica, em parceria com a PUC-Rio, no Rio de Janeiro ${ }^{34}$.

O Seminário de Brasília teve como conclusão alguns pontos importantes que influenciaram o Projeto do Novo Código de Processo Civil no que tange à inclusão de cláusula de foro em contratos internacionais, como o

\footnotetext{
${ }^{34}$ Ibid. 151 p.
} 
reconhecimento pelo Brasil da Convenção - $\operatorname{logo}$, de que tal cláusula não contraria a soberania nacional - assim como das vantagens da Convenção para os países do Mercosul, pois a Convenção não se contrapõe a instrumentos jurídicos regionais tal como o Protocolo de Buenos Aires.

Dessa maneira, a adoção da Convenção pelo Brasil proporcionaria apenas vantagens no plano dos negócios internacionais e alinharia o Brasil ao entendimento firmado entre os Países que participam da Conferência de Haia.

\subsubsection{Mercosul}

Como acima mencionado, no âmbito de seus compromissos no Mercosul, o Brasil se submete ao Protocolo de Buenos Aires sobre Jurisdição Internacional em Matéria Contratual, promulgado pelo Decreto 2.095/ 1996, o qual, em seu artigo $4^{35}$, normatiza o que a Convenção pretende regular em cenário mais amplo. Por sua vez, a União Europeia possui o Regulamento $44 / 2001^{36}$ que, em seu artigo 23, estabelece um regime favorável à escolha de eleição de foro.

\footnotetext{
${ }^{35}$ Artigo 4. Nos conflitos que decorram dos contratos internacionais em matéria civil ou comercial serão competentes os tribunais do Estado-Parte em cuja jurisdição os contratantes tenham acordado submeter-se por escrito, sempre que tal ajuste não tenha sido obtido de forma abusiva.

2. Pode-se acordar, igualmente, a eleição de tribunais arbitrais. (Promulgado pelo Decreto 2.095/1996)

${ }^{36}$ Artigo 23. 1. Se as partes, das quais pelo menos uma se encontre domiciliada no território de um Estado-Membro, tiverem convencionado que um tribunal ou os tribunais de um Estado-Membro têm competência para decidir quaisquer litígios que tenham surgido ou que possam surgir de uma determinada relação jurídica, esse tribunal ou esses tribunais terão competência. Essa competência será exclusiva a menos que as artes convencionem em contrário. Este pacto atributivo de jurisdição deve ser celebrado: a) Por escrito ou verbalmente com confirmação escrita; ou b) Em conformidade com os usos que as partes estabelecerem entre si; ou c) No comércio internacional, em conformidade com os usos que as partes conheçam ou devam conhecer e que, em tal comércio, sejam amplamente conhecidos e regularmente observados pelas partes em contratos do mesmo tipo, no ramo comercial considerado. 2. Qualquer comunicação por via eletrônica que permita um registro duradouro do pacto equivale à "forma escrita". 3. Sempre que tal pacto atributivo de jurisdição for celebrado por partes das quais nenhuma tenha domicílio num Estado-Membro, os tribunais dos outros Estados-Membros não podem conhecer do litígio, a menos que o tribunal ou os tribunais escolhidos se tenham declarado incoomeptentes.4. O tribunal ou os tribunais de um Estado-Membro, a que o acto constitutivo de um
} 
À vista disso, o respeito e reconhecimento da cláusula de eleição de foro já é uma realidade para os países integrantes do Mercosul, apesar de não ser da jurisdição brasileira, o que contribui enormemente para o desenvolvimento dos negócios na região. O mesmo pode ser dito para os países europeus signatários do Regulamento 44/2001.

Ademais, o Mercosul possui também o Protocolo de Las Leñas de 1992, promulgado pelo Decreto 6.891/2009, que regula a Cooperação e Assistência Jurisdicional em matéria civil, comercial, trabalhista e administrativa entre os Estados-Partes. Assim, já existe uma vontade a nível regional de reconhecer e de honrar a liberdade de as partes convencionarem como melhor entenderem. A Convenção, portanto, visa ampliar o tratamento do tema do âmbito regional para o plano internacional, estando em conformidade com o que já é aceito e praticado regionalmente por muitos países.

Por conseguinte, a adesão do Brasil aos protocolos do Mercosul e a sua participação na Conferência da Haia de Direito Privado demonstram a sua abertura aos processos de cooperação internacional. A adesão à Convenção de Haia sobre a escolha de foro aperfeiçoaria essa cooperação já existente e serviria para melhorar as condições de brasileiros e estrangeiros envolvidos em negócios transnacionais com o Brasil, além de diminuir o chamado "custo Brasil", pois a incerteza de validade de uma cláusula de eleição de foro pode ser interpretada como um aumento de custo ao fazer negócios no Brasil por ter que eventualmente custear uma ação no país mesmo sendo convencionado outro local. Em vista disso, embora já existam os protocolos do Mercosul e

\footnotetext{
"trust" atribuir competência, têm competência exclusiva para conhecer da acção contra um fundador, um "trustee" ou um beneficiário de um "trust", se se tratar de relações entre essas pessoas ou dos seus direitos ou obrigações no âmbito do "trust". 5. Os pactos atributivos de jurisdição bem como as estipulações similares de actos constitutivos e "trust" não produzirão efeitos se forem contrários ao disposto nos artigos $13^{\circ}, 17^{\circ}$ e $21^{\circ}$, ou se os tribunais cuja competência pretendam afastar tiverem competência exclusiva por força do artigo $22^{\circ}$.
} 
outras convenções que abordam a questão da escolha de foro, a Convenção continua tendo relevância, pois contribuiria para conciliar todos os demais acordos já existentes e serviria para os países que não são parte de tais acordos, conferindo-lhes maior certeza jurídica.

\subsection{Histórico Legislativo do Artigo 25}

\subsubsection{O Anteprojeto do Novo Código de Processo Civil}

\subsubsection{Considerações Gerais}

O Novo Código de Processo Civil irá substituir o CPC de 1973, dez anos após a reforma do Judiciário ${ }^{37}$. Em 2009, o então presidente do Senado, José Sarney, tomou para si a iniciativa de formar uma comissão de juristas responsáveis para elaborar o Anteprojeto do Novo Código de Processo Civil, mediante o Ato 379/09 e o Ministro Luiz Fux foi designado Presidente da Comissão de Redação do Anteprojeto, ao lado da Teresa Arruda Alvim Wambier, a Relatora.

De acordo com a Exposição de Motivos do Anteprojeto (Exposição), este funde $\mathrm{o}$ reconhecimento $\mathrm{e}$ realização dos direitos com as garantias constitucionais do Estado Democrático de Direito brasileiro, uma vez que o atual Código de Processo Civil de 1973 tem se mostrado carecedor de real efetividade, já que as normas de direito material tornam-se ilusórias em virtude das regras processuais nos moldes do CPC.

A Exposição continua por afirmar que enquanto o CPC de 1973 operou de forma satisfatória durante algumas décadas, na atualidade este já se mostrava ineficiente e defasado. No interregno de 1973 a 2015 diversas reformas foram realizadas com o objetivo de alterar e adaptar as normas processuais às mudanças na sociedade e nas instituições. Exemplo disto foram a inclusão do Instituto da antecipação de tutela em 1994, e, em 1995, a

\footnotetext{
${ }^{37}$ Que se deu com a Emenda Constitucional 45 de 30 de Dezembro de 2004
} 
alteração do Regime do agravo, e, mais recentemente, as leis que modificaram sua execução.

A visão geral do Anteprojeto, novamente de acordo com a Exposição, foi a de preservar a forma sistemática das normas processuais, conferindo para tal um caráter pragmático a fim de se obter um grau de elevada funcionalidade, sem romper com o passado, apenas dando um passo à frente para garantir, de fato, eficiência ao sistema.

Assim, a Exposição conta que o Anteprojeto se propôs a trabalhar na linha de resolver problemas, no campo metódico de resolução de conflitos em harmonia com os valores constitucionais. Isto porque "a coerência substancial há de ser vista como objetivo fundamental, todavia, e mantida em termos absolutos, no que tange à Constituição Federal da República” 38 . Assim sendo, o Novo CPC teve a pretensão de ser mais justo, rápido e menos complexo frente às necessidades sociais, enfrentando primordialmente a questão de acesso à Justiça e seus obstáculos corriqueiros como: excessiva formalidade, duração do processo e o seu alto custo.

Visando a simplificação do sistema processual, a Comissão se orientou por cinco objetivos:

“1) estabelecer expressa e implicitamente verdadeira sintonia fina com a Constituição Federal; 2) criar condições para que o juiz possa proferir decisão de forma mais rente à realidade fática subjacente à causa; 3) simplificar, resolvendo problemas e reduzindo a complexidade de subsistemas, como, por exemplo, o recursal; 4) dar todo o rendimento possível a cada processo em si mesmo considerado; e, 5) finalmente, sendo talvez este último o objetivo parcialmente alcançado pela realização daqueles mencionados antes, imprimir maior grau de organicidade ao sistema, dando-lhe, assim, mais coesão”.

À vista disso, incluem-se no novo Código de forma expressa os princípios constitucionais, porém, em sua versão processual. A intenção disto

\footnotetext{
${ }^{38}$ Anteprojeto do Novo Código de Processo Civil, Exposição de Motivos, Brasília 2010, 13 p.
} 
foi aproximar o Código da Constituição, assegurando materialmente a lei, como diz a Exposição.

No que concerne a tornar o processo mais célere, o novo Código preconizou a ideia de uniformização de jurisprudência. A fragmentação do sistema ocorre quando os Tribunais possuem posicionamentos incompatíveis e diferentes no que diz respeito à uma mesma norma jurídica. O resultado disso é insegurança jurídica para os jurisdicionados, já que dependendo do tribunal julgador, situações idênticas possam receber tratamento e interpretação diversa.

Isto posto, inspirando-se nos institutos da Súmula Vinculante e do Regime de Julgamento Conjunto de Recursos Especiais e Extraordinários Repetitivos, o novo Código incentiva a uniformização da jurisprudência, tendo em vista as decisões dos tribunais superiores e de segundo grau, uma vez que estes tribunais existem justamente para moldar o ordenamento jurídico. Dessa maneira, é necessário que os Tribunais mantenham a sua jurisprudência estável.

Para tanto, o novo Código adotou de forma expressa o princípio de que, uma vez firmada jurisprudência em determinado sentido, esta deve ser mantida como norma, a não ser que surjam relevantes razões que justifiquem a sua modificação, posto que a mudança de jurisprudência produz resultados análogos aos efeitos ex tunc.

Assim, pode-se entender que as mudanças mais significativas do sistema processual no que diz respeito ao objetivo de harmonizá-lo com a Constituição Federal, são aquelas relacionadas à uniformidade e à estabilidade jurisprudencial. Estas mudanças, por sua vez, conseguem concretizar o princípio da segurança jurídica, proporcionando uma vida mais "segura" aos jurisdicionados. Além disso, o caminho para a diminuição do número de 
recursos tomado pelo novo Código é uma decorrência de uma jurisprudência mais estável e uniforme.

Ademais, o novo Código pretendeu converter o processo em instrumento compreendido no contexto social no qual o seu resultado surtirá efeitos, entendendo-se que a "satisfação efetiva das partes pode dar-se de modo mais intenso se a solução é por elas criada e não imposta pelo juiz",39. Isto nada mais é do que uma regra processualística contemporânea que privilegia o conteúdo e não a forma, materializando o princípio da instrumentalidade.

A Exposição informa que, com a finalidade de simplificar o sistema processual, muitos procedimentos especiais foram extintos, tais como as ações cautelares nominadas. Isto porque se considerou importante que o Poder Judiciário reaja de forma rápida, não apenas em situações de urgência, de modo a evitar o perecimento do direito. E, de fato, a Comissão do Novo Código de Processo Civil conseguiu simplificar o sistema recursal. No entanto, tal simplificação de forma alguma cerceou o direito à defesa — princípio constitucionalmente previsto, e o resultado foi maior rendimento do processo considerado individualmente.

Ao se permitir que o processo tenha o maior rendimento possível, estendeu-se a autoridade da coisa julgada às questões prejudiciais ${ }^{40}$. Na base de todo o Projeto, esteve o objetivo geral de conferir mais organicidade ao sistema processual brasileiro, consequentemente conferindo maior coesão às suas regras.

Dessa maneira, a Comissão de Juristas encarregada de reformar o processo civil, o fez buscando o equilíbrio entre conservação e inovação, de

\footnotetext{
${ }^{39}$ Idem. 22 p.

${ }^{40}$ Idem. 28 p.
} 
acordo com a própria Exposição, pois não se quis romper com o passado para ter um presente mais eficiente, inspirado em direito estrangeiro. A elaboração do Novo Código de Processo Civil incorporou avanços tornando o sistema mais adequado à Constituição Federal da República, com o intuito de se ter um sistema mais uno, ágil e que, de fato, garanta um processo justo e célere.

O Anteprojeto, antes de qualquer coisa, foi elogiado pelo seu caráter democrático. Durante os seus anos de elaboração realizaram-se intensos debates, entre operadores de direito, instituições que fazem parte do sistema de Justiça e, acadêmicos, assim como a sociedade como um todo. Por exemplo, apenas na Câmara dos Deputados, foram realizadas 15 audiências públicas, conferências estaduais, foram ouvidos mais de 140 palestrantes, o portal edemocracia registrou 25.300 acessos, 282 sugestões, 143 comentários e 90 emails ${ }^{41}$.

\subsubsection{Surgimento do Artigo 25}

No que concerne o Artigo 25, este surgiu durante $3^{\mathrm{a}}$ Audiência Pública realizada no dia 11.03.2010, na cidade do Rio de Janeiro, no auditório do Tribunal de Justiça do Rio de Janeiro; estando presentes os membros da Comissão, Ministro Luiz Fux, Teresa Arruda Alvim Wambier, Benedito Cerezzo Pereira Filho e Paulo Cezar Pinheiro Carneiro ${ }^{42}$. Dentre os convidados ouvidos, estiveram vários membros do Tribunal de Justiça do Rio de Janeiro, da OAB, advogados, professores, procuradores, representantes de sindicatos, entre outros.

Dentre os principais temas abordados pelos convidados, esteve a matéria da Competência Internacional, em que foi levantada a questão da

\footnotetext{
${ }^{41}$ WAMBIER, Teresa de Arruda Alvim; DANTAS, Bruno; FREIRE, Alexandre; NUNES, Marcelo Guedes. O Novo CPC dará maior racionalidade ao Sistema de Justiça. 12/07/2013. Disponível em <http://www.migalhas.com.br/dePeso/16,MI182384,41046-

$\mathrm{O}+$ novo+CPC+dara+maior+racionalidade+ao+sistema+de+Justica $>$. Acesso em 09.03.2015

${ }^{42}$ Anteprojeto do Novo Código de Processo Civil, Brasília 2010, 323 p.
} 
necessidade de efetividade à cláusula de eleição de foro estrangeiro (por exemplo, regramento da Convenção de Haia sobre escolha de foro $)^{43}$, bem como questões concernentes à cooperação jurídica internacional.

Pode-se identificar a origem do Artigo 25 (que no Anteprojeto era o Artigo 24) a partir desse momento, e verificar a influência que a Convenção de Haia teve em sua elaboração como forma de adequar e atualizar a legislação brasileira em conformidade com a pratica internacional, para garantir maior eficiência ao sistema como um todo.

\subsubsection{Projetos e Emendas}

Tendo sido o Ato 379/09 que instituiu o Anteprojeto do Novo Código de Processo Civil, de autoria Senador José Sarney, o trâmite do Anteprojeto se iniciou no Senado, sob a designação de PLS 166/10. Ao sair do Senado para ter sua aprovação e votação na Câmara dos Deputados, recebeu a designação de PL 8.046/10, sendo objeto de discussão em comissão na qual o deputado Fábio Trad (PMDB/ MS) foi presidente e o deputado Paulo Teixeira (PT/ SP) o relator-geral.

No Senado, o prazo para sugestões ao Projeto, sejam estas aditivas ou excludentes, se encerrou em 08 de agosto de 2010 tendo sido mais de mil e quinhentas páginas de sugestões apresentadas. Com relação à cláusula de foro estrangeiro, que se encontrava no então artigo 24 do Anteprojeto, houve sugestões de duas entidades para alteração de sua redação com base em princípios diferentes, de uma terceira contra a sua inclusão no texto do Código, além da sugestão do Senador Marconi Perillo também no sentido de sua

\footnotetext{
${ }^{43}$ Idem. 327 p.
} 
exclusão. Essas informações, e as seguintes, estão todas disponíveis no próprio site do Senado referente ao PLS $166 / 10^{44}$.

As Secretarias de Reforma do Judiciário e de Assuntos Legislativos do Ministério da Justiça arguiram que a redação do artigo como estava ia de encontro àquilo previsto na Constituição Federal, assim como contra o Direito do Consumidor. Dessa maneira, tomando como exemplo o contrato de adesão em questões de softwares em que o consumidor pode usar o foro de sua residência, sugeriram que fosse acrescentado um parágrafo a mais para que, havendo cláusula de foro estrangeiro exclusiva, esta poderia ser questionada ${ }^{45}$.

A Associação Nacional dos Defensores Públicos (ANADEP), preocupada com a violação de direitos fundamentais, em especial o direito à ampla defesa, também sugeriu a mudança de redação do artigo ao entender que estes direitos não podem ser sacrificados pela determinação de uma cláusula de foro exclusivo estrangeira. Assim, sugeriu a inclusão de um parágrafo que determinaria a validade da cláusula apenas quando não houvesse situação de vulnerabilidade social ou econômica que implicaria na restrição de direitos fundamentais ${ }^{46}$.

\footnotetext{
${ }^{44}$ Para maiores informações acessar o site em < http://www.senado.gov.br/atividade/materia/detalhes.asp?p_cod_mate=97249>

45 "O art. 24 deste projeto que trata de exclusão de autoridade judiciária brasileira e o processamento e o julgamento das ações quando houver cláusula de eleição de foro exclusivo estrangeiro, arguido pelo réu na contestação parece ir de encontro ao previsto na constituição da república e bem assim ao direito consumerista. Atualmente, a jurisprudência tem entendido que no caso dos contratos de adesão, por exemplo, submetido na questão de softwares, o consumidor pode usar o foro de sua residência. Todavia, com a redação do art.24 como está, todos os contratos de softwares que contenham em seus termos de uso uma cláusula de eleição de foro, não poderão ter causas julgadas no Brasil. Logo, manifestamo-nos pela inclusão de um parágrafo primeiro com a renumeração dos demais, para que se deixe claro que a cláusula de eleição de foro poderá ser questionada." Disponível em <http://www.senado.gov.br/atividade/materia/getPDF.asp?t=83351\&tp=1> acesso em 18.05.2015 às 10:36.

46 "A proposta tem por intuito evitar que grupos estrangeiros vulneráveis residentes no país possam ter seu direito à ampla defesa violado em razão doo estabelecimento de cláusula de foro exclusivo estrangeiro, em respeito ao disposto no caput do art. $5^{\circ}$ da Constituição Federal." Disponível em < http://www.senado.gov.br/atividade/materia/getTexto.asp?t=83642\&c=PDF\&tp=1> acesso em 18.05.2015 às 10:57
} 
Já a Associação dos Magistrados Brasileiros (AMB) sugeriu a rejeição do artigo baseando-se nas palavras do Ministro Athos Gusmão Carneiro, no qual adverte que o artigo, além de inconstitucional por ferir o princípio constitucional de acesso à Justiça, colocando o judiciando em posição fragilizada, já que poderá, possivelmente, ficar privado da tutela do judiciário nacional, implica em descredito ao Poder Judiciário brasileiro ${ }^{47}$.

O Senador Marconi Perillo, acolhendo também a tese do Ministro Athos Gusmão Carneiro, em 11 de novembro de 2010, apresentou emenda ao Projeto no qual sugeria que o artigo 24 fosse suprimido e os demais renumerados. Alegou sua inconstitucionalidade por ferir o artigo 5, inciso XXXV da Constituição Federal ${ }^{48}$.

Em 24 de novembro de 2010, o Relator do Projeto, Senador Valter Pereira apresentou o Parecer da Comissão Temporária da Reforma do Código de Processo Civil. Nele foi mencionado a emenda de exclusão do artigo 24, apresentada pelo Senador Marconi Perillo. Tal emenda foi acolhida ${ }^{49}$ ao

47 “isso atenta profundamente contra o princípio constitucional que garante o EFETIVO acesso ao Poder Judiciário em qualquer caso de lesão de direito, ou ameaça de lesão (CF, art. $\left.5^{\circ}, X X X V\right)$. Só como exemplo: a empresa de origem multinacional, embora com sede regional em nosso país, poderá inserir em seus contratos, firmados no Brasil, a aludida cláusula, mesmo se o outro contratante for cidadão ou empresa brasileira, e os contratos disserem a respeito a negócios a serem inteiramente cumpridos no Brasil. Nesses termos, o contratante prejudicado pelo inadimplemento contratual, ou que pretenda a execução do contrato, poderá ser obrigado a litigar (?) no foro de Xangai, ou de Genebra, ou de Nova Iorque, ou de Tóquio, ou de Dubai. A 'novidade', trazida pelo art. 24, data vênia, é inconstitucional e altamente nociva à efetividade da tutela jurídica, que o novo CPC pretende aperfeiçoar. Inclusive, implica descrédito, capitis diminutio ao Poder Judiciário nacional." Disponível em< http://www.senado.gov.br/atividade/materia/getPDF.asp?t=83497\&tp=1 > acesso em 18.05.2015 às 10:38.

48 "O artigo 24 exclui a competencia da Justiça brasileirade julgamento de ações decorrentes de contratos em que "houver cláusula de eleição de foro exclusivo estrangeiro". Não é exigida a mínima vinculação da lide ao Estado estrangeiro. Este artigo do Projeto atenta contra o princípio constitucional que garante o efetivo acesso ao Poder Judiciário em qualquer caso de lesão de direito, ou de ameaça de lesão (CF, art. $\left.5^{\circ}, X X X V\right)$. A inovação trazida pelo art. 24 é inconstitucional $e$ altamente nociva à efetividade da tutela jurídica, que o novo CPC pretende aperfeiçoar. Inclusiva implica descrédito, capitis diminutio ao Poder Judiciário nacional". Disponível em <http://www.senado.gov.br/atividade/materia/getPDF.asp?t=83510\&tp=1> acesso em 18.05.2015 às $10: 48$

${ }^{49}$ II.4.117 - Emenda $n^{\circ} 168$ A Emenda n. 168 merece ser acolhida. Realmente, a regra projetada para o art. 24 atenta contra o princípio constitucional que garante o efetivo acesso ao Poder 
entender que a sua permanência, de fato, seria inconstitucional. O Parecer foi aprovado no dia 1 de dezembro do mesmo ano e o PLS 166/2010 fora aprovado cinco dias depois sendo remetido para a Câmara dos Deputados no dia 20 de dezembro.

Em 22 de Dezembro de 2010, a Câmara dos Deputados recebeu Ofício 2428/2010 do Senado Federal, que submetia a revisão do Projeto de Lei do Senado 166/2010, da reforma do Código de Processo Civil. Os Deputados tiveram, basicamente, prazo de um ano (incluídos os pedidos de prorrogação) para formular as suas sugestões de emenda ao Projeto. Até 22 de Dezembro de 2011, novecentas emendas foram apresentadas. Estes dados e informações estão todos disponíveis no site da Câmara referente ao PL 8.046/10 $0^{50}$.

Dentre essas emendas, três voltavam a propor a reinclusão do artigo que disciplinava a questão de cláusula de eleição de foro no âmbito da competência concorrente do Estado brasileiro.

Em 28 de setembro de 2011, o Deputado Paes Landim e o Deputado Sandro Mabel encaminharam proposta de emenda aditiva, que defendia a reinclusão do artigo 25. Apesar de as emendas terem sido apresentadas de forma separada, a justificativa foi a mesma. Houve preocupação com a vontade das partes que seriam afetadas, assim como com a fragilidade da sentença brasileira ao vir a ser executada no exterior, já que a competência sendo

\footnotetext{
Judiciário em qualquer caso de lesão de direito, ou de ameaça de lesão $\left(C F\right.$, art. $\left.5^{\circ}, X X X V\right)$, já que permite a exclusão de certas questões da jurisdição brasileira. (Parecer $\mathrm{n}^{\circ}$, de 2010 da Comissão Temporária da Reforma do Código de Processo Civil, sobre o Projeto de Lei do Senado n ${ }^{\circ} 166$ de 2010, que dispõe sobre a reforma do Código de Processo Civil, e proposições anexadas. Relator: Senador Valter Pereira, $228 \quad$ p. $\quad$ Disponível em <http://www.senado.gov.br/atividade/materia/getPDF.asp?t=83984\&tp=1> acesso em 18.05.2015 às 10:50

${ }^{50}$ Para maiores informações acessar o site em

<http://www.camara.gov.br/proposicoesWeb/fichadetramitacao?idProposicao=490267>
} 
concorrente, não haveria garantia do cumprimento de tal sentença, prejudicando as relações comerciais brasileiras ${ }^{51}$.

Já o Deputado, Nelson Marchezan Júnior, em 23 de Novembro de 2011, apresentou emenda aditiva no mesmo sentido, reconhecendo que a exclusão do artigo significaria comprometimento da vontade das partes. Pela proposta, o artigo previa a exceção da regra de competência brasileira, de modo que, quando houvesse a cláusula de eleição de foro exclusivo estrangeiro, o afastamento da jurisdição nacional teria de ser respeitado.

O mesmo defendeu que a inclusão de tal cláusula em um contrato internacional é prática comum para evitar que uma ação seja julgada por diversos países que sejam simultaneamente competentes, uma vez que por mais que existam esforços para uniformizar as regras internacionais sobre a questão de jurisdição internacional, ainda inexistem regras universalmente aceitas sobre o assunto. Assim sendo, repetidas vezes o autor e réu recorrem a Justiças diferentes para se utilizarem da que lhe seja mais benéfica. Dessa maneira, para que as partes tenham mais certeza sobre o local de um possível futuro litígio, lhes é facultado, via cláusula contratual e por meio do princípio da autonomia da vontade, especificar o local do tribunal competente no contrato e isto confere mais segurança na esfera de contratação internacional.

O Deputado ressaltou que, por mais que no Brasil seja permitido a eleição de foro em contratos internos, não havia norma que tratasse da matéria para os contratos internacionais e, em razão de não haver jurisprudência

51 "O Artigo deve ser mantido e não excluido, pois afeta a vontade das partes, especialmente de empresas que dependem de fornecimento de serviços ou de bens estrangeiros, para as quais é preferivel e necessária a cláusula de foro de eleição. Se mantida a exclusão, como executar uma sentença no exterior para forçar o cumprimento dessa sentença?" Disponível em < http://www.camara.gov.br/proposicoesWeb/prop_mostrarintegra?codteor=925536\&filename=Tramita cao-EMC+113/2011+PL804610+\%3D\%3E+PL+8046/2010> e em < http://www.camara.gov.br/proposicoesWeb/prop_mostrarintegra?codteor $=925540 \&$ filename $=$ Tramita cao-EMC+116/2011+PL804610+\%3D\%3E+PL+8046/2010> acesso em 18.05.2015 às 11:06 
pacífica sobre o tema, o reconhecimento da validade da cláusula muitas vezes não se concretizava. Isto posto, a proposta do novo CPC respeita a opção feita pelas partes contratantes e representa um avanço para o sistema jurídico brasileiro com relação as práticas utilizadas no comércio internacional.

Destacou ainda estar atualmente em avaliação a conveniência de que o Brasil assine a Convenção de Haia sobre a Cláusula de Eleição de Foro, de cuja negociação o Brasil participou. Assim sendo, a tendência seria a de alinhar-se ao caminho proposto pela Convenção. Por fim, defendeu o Deputado que a inclusão do artigo adequaria a legislação brasileira aos parâmetros já existentes em outros países ${ }^{52}$.

52 "A redação ora sugerida constava no art. 24 do anteprojeto do novo Código de Processo Civil, devendo ser mantida a previsão legal, e não excluída, nesta reforma, pois afeta a vontade das partes, especialmente de empresas que dependem do fornecimento de serviços ou de bens estrangeiros, para as quais é preferível e necessária a cláusula de eleição de foro. Se excluída esta previsão, como se poderá executar uma sentença no exterior para exigir o cumprimento da decisão judicial? Observa-se que, pela proposta, foi estabelecido que caberá à autoridade brasileira processar e julgar as ações em que as partes, tácita ou expressamente, se submeterem à jurisdição brasileira. $O$ artigo 24 do anteprojeto do CPC trazia exceção a esta regra, determinando a não caber à autoridade judiciaria brasileira julgar os casos em que houver cláusula de eleição de foro exclusivo quando eleito o foro estrangeiro. Ou seja, havendo cláusula expressa indicando a jurisdição nacional, nada pode demover a ação da jurisdição brasileira, e para que a regra tenha efeito bilateral, se por seu turno houver no contrato uma cláusula excluindo a jurisdição brasileira, elegendo-se o foro estrangeiro, a exclusão terá que ser respeitada. A inclusão de cláusulas de escolha de foro em contratos internacionais é uma prática necessária uma vez que diversos países podem ser competentes ao mesmo tempo, em face da inexistência de regras internacionais uniformes e universalmente aceitas sobre jurisdição internacional. Quando o litígio surge, frequentemente autor e réu recorrem a judiciários distintos, porque procuram utilizar o tribunal do país que mais lhes beneficia, seja em decorrência da lei aplicável ao mérito ou ao processo no foro escolhido. Para dar às partes certeza sobre o local de um futuro litígio, permite-se, por meio do princípio da autonomia da vontade a liberdade de escolha, via cláusula contratual sobre foro. Ademais, garantir o respeito pelos tribunais a essa escolha feita pelas partes é uma forma de auxiliar a obtenção de segurança jurídica na contratação internacional. No Brasil, embora seja conhecida e permitida a escolha do foro nos contratos internos, não havia norma específica para os contratos internacionais e a jurisprudência sobre o tema não é pacífica, nem sempre reconhecendo a validade da prorrogação de foro determinada. A proposta do novo CPC, que respeita a opção de foro das partes, representa grande avanço para tornar o país mais afeito às cláusulas já classicamente utilizadas no comércio internacional. No plano global, a Conferência de Haia para o Direito Internacional Privado realizou uma convenção internacional com esse propósito, a Convenção de Haia sobre a cláusula de eleição de foro, de 2005. A Convenção está em processo de ratificação pelos signatários, sendo de se destacar a União Europeia e os Estados Unidos da América. Um dos princípios mais importantes da Convenção é garantir que a escolha das partes por um foro exclusivo para dirimir suas controvérsias seja respeitado de forma automática pelos países signatários. O Brasil participou das negociações da Convenção de 2005 e está avaliando se vai assinar a Convenção, mas o artigo inserido no Projeto de Código de Processo Civil demonstra que o país caminha na direção proposta pela convenção, considerado como um instrumento valioso para a 
Pelas justificativas apresentadas pelos deputados, pode-se notar a preocupação dos mesmos com, não somente a autonomia das partes, mas com a segurança nas relações comerciais internacionais do Brasil e com a possibilidade da execução das sentenças no exterior. Ademais, foi especificamente citado o cenário atual da eleição de foro em contratos internacionais ao fazer-se referência à Conferência de Haia, na qual o Brasil participou das negociações da Convenção, e apesar de ainda não tê-la assinado, a inserção do artigo no texto do novo CPC caminha na direção da Convenção. Assim sendo, a inclusão do artigo significaria um instrumento valioso para se ter um comércio internacional mais transparente e com normas mais eficazes, dado que a jurisprudência brasileira se mantinha oscilante em se tratando de tal cenário.

Como a pretensão do Novo Código de Processo Civil foi a de atualizar, melhorar e adequar a legislação aos parâmetros já em vigor em outros países, levando em conta as peculiaridades que são próprias da tradição processual brasileira, o artigo foi novamente inserido no texto do Novo CPC pela Câmara dos Deputados. Assim, o conteúdo do artigo 25, na verdade, nasceu no Anteprojeto, porém, sob a numeração de artigo 24, foi retirado do texto do projeto do novo CPC no Senado, e quando voltou na Câmara dos Deputados a

\footnotetext{
promoção de normas eficazes e transparentes para o comércio internacional. A Convenção baseia-se em três regras para os tribunais. Na primeira, um tribunal designado pelas partes, sendo de um país signatário, não pode exirmirse (sic) de julgar a causa, salvo algumas exceções bastante restritas. A ideia é evitar que um tribunal escolhido possa recusar, com base em suas normas internas, de julgar o caso em questão. A segunda regra cuida do tribunal em que a ação foi proposta, mas que não é o tribunal escolhido pelas partes. Esta é a segunda regra-chave da Convenção. Se o tribunal escolhido é a de um país parte da convenção, o outro tribunal, em que a ação foi iniciada, deve abster-se de aceitar a jurisdição, mesmo que a sua lei interna lhe conferisse competência para a matéria, em respeito ao acordo internacional em questão. A terceira regra diz respeito ao reconhecimento da decisão obtida na jurisdição escolhida, que não pode ter recusado o seu reconhecimento e execução pelo tribunal de outro país. O projeto do novo CPC respeita essas regras nos artigos citados e auxilia a adequação da legislação brasileira aos novos parâmetros já em vigor nos outros países.". Disponível em 
sua numeração foi alterada para 25 , havendo a renumeração dos demais artigos.

Em 26 de março de 2014, a Redação Final do Projeto de Lei 8.046/2010 foi à votação no plenário da Câmara dos Deputados em Sessão Deliberativa Ordinária. Após a sua aprovação, no dia seguinte, foi remetida ao Senado Federal.

Já em 25 de fevereiro de 2015 a Mesa Diretora da Câmara dos Deputados recebeu Ofício 86/15 (SF) solicitando remessa para sanção presidencial. O Novo Código de Processo Civil foi transformado em Lei Ordinária 13.015/2015, no dia 16 de março do mesmo ano, tendo sido vetado parcialmente. 


\section{CONCLUSÃO}

Como foi possível ver ao longo desta monografia, o reconhecimento da cláusula de eleição de foro em contratos internacionais mudou bastante com a inclusão de um artigo no Novo Código de Processo Civil que normatiza a sua efetividade.

Quando o tema ainda era regulado pelo artigo 88 do CPC de 1973 havia, oscilação quanto à aplicabilidade e à validade da cláusula de eleição de foro, uma vez que os Tribunais, praticamente de forma unanime, entendiam que o artigo 88 tinha força imperativa. Isto é, mesmo estando a cláusula inserida em contrato internacional litigioso sob análise da Justiça, na ocorrência de qualquer dos fatos contidos no artigo 88, a cláusula era desconsiderada. Para a doutrina, a matéria também não era pacífica, havendo os que defendiam a imperatividade da norma contida no artigo 88 , e outros que entendiam que deveria ser priorizada a autonomia da vontade das partes contratantes.

No âmbito internacional, viu-se que o tema era mais pacífico, havendo esforços no sentido de consolidar o entendimento da força vinculativa nas jurisdições estatais da cláusula de eleição de foro que elegesse foro estrangeiro. O resultado mais perceptível disso foi a Convenção de Haia sobre escolhas de foro de 2005, que serviu como base e inspiração do artigo 25 do Novo CPC.

Como forma de trazer para o Brasil os novos parâmetros de direito internacional privado, buscou-se, primeiramente, na forma do artigo 24 do Anteprojeto do Novo Código Civil, materializar o que havia sido estipulado na Convenção acima mencionada.

No entanto, uma vez no Senado Federal, tal artigo foi retirado do texto do Projeto de Lei que tratava do Novo CPC. O Senado acatou o entendimento de que uma convenção entre partes privadas não poderia afastar o império jurisdicional do Estado brasileiro. No entanto, uma vez na Câmara dos 
Deputados, o artigo foi reincluído - e renumerado - no texto do Projeto do Novo CPC, baseando-se nos padrões internacionais em vigor, o que foi visto como uma forma de finalmente colocar o Brasil dentro de tais padrões. Quando o Projeto, por fim, foi a sanção presidencial, o artigo permaneceu no texto (artigo 25).

Destarte, quando o Novo CPC entrar em vigor em março de 2016, contratos internacionais que tiverem uma cláusula de eleição de foro estrangeiro não mais estarão à mercê da vontade do julgador. Tal cláusula terá sua validade reconhecida e afastar-se-á a competência brasileira. Dessa maneira, a cláusula agora será regulada de modo a conferir previsibilidade para seus optantes e garantir segurança jurídica nos negócios internacionais. 


\section{BIBLIOGRAFIA}

CINTRA, Antonio Carlos de Araújo; GRINOVER, Ada Pelegrini; DINAMARCO, Cândido Rangel. Teoria Geral do Processo. São Paulo: Malheiros Editores, 27ª edição, 2011;

ARAUJO, Nádia de. Direito internacional privado: teoria e prática brasileira. Rio de Janeiro: Renovar, $3^{\mathrm{a}}$ edição, 2006;

MAZZUOLI, Valério Oliveira de. Curso de Direito Internacional Público. $7^{\mathrm{a}}$ ed.. São Paulo: Revista dos Tribunais, 2013;

CARNEIRO, Athos Gusmão. Competência internacional concorrente. Artigo 88 do CPC e foro de eleição. Revista Forense, v. 352, pp.37-48;

MOREIRA, José Carlos Barbosa. Competência internacional- prova de direito estrangeiro- ônus de quem o alega. Revista de processo, v. 91, 1998, pp. 275291 ;

TIMM, Luciano Benetti. A cláusula de eleição de foro versus a cláusula arbitral em contratos internacionais: qual é a melhor opção para a solução de disputas entre as partes? Revista de Arbitragem e Mediação, vol. 10, 2006, pp. 20-38;

ARAUJO, Nádia de; GAMA, Lauro Jr.; SPITZ, Lidia. Cláusula de eleição de foro estrangeiro. Valor econômico. 24 de setembro de 2012;

ARAUJO, Nádia de; VARGAS, Daniela. A Conferência de Haia de Direito Internacional Privado: Reaproximação do Brasil e análise das convenções processuais. Revista de Arbitragem e Mediação, vol. 35, 2012, pp. 189-212;

ARAUJO, Nádia de. Convenção de Haia sobre escolha de foro e o Brasil: necessidade de sua adoção. Revista Brasileira de Arbitragem, vol. 18, 2008, pp. 27-38; 
ARAUJO, Nádia de; GAMA, Lauro Jr.; VARGAS, Daniela. Temas de Direito Internacional Privado no Projeto de Novo Código de Processo Civil. Revista de Arbitragem e Mediação, vol. 28, 2011, pp. 147-158;

NARDI, Marcelo de. A lei e o foro de eleição em contratos internacionais: uma visão brasileira, in RODAS, João Grandino (Coord), Contratos Internacionais, $3^{\mathrm{a}}$ edição. São Paulo: Editora Revista dos Tribunais, 2002;

FILHO, Antenor Pereira Madruga. A Renúncia à Imunidade de Jurisdição pelo Estado Brasileiro e o novo Direito da Imunidade de Jurisdição. Rio de Janeiro: Renovar, 2003;

BORN, Gary B. International Commercial Arbitration. Chapter 14: Selection of Arbitral Seat in International Arbitration. Kluwer Law International; Kluwer Law International 2014, Second Edition;

MOREIRA, José Carlos Barbosa. Garantia Constitucional do Direito à Jurisdição - Competência Internacional da Justiça Brasileira. Prova do Direito Estrangeiro". Revista Forense, Vol. 343, 1998;

REYNES, Victor Bonnin. Forum non conveniens: A Hidden Ground to Refuse Enforcement of Arbitral Awards in the United States, Journal of International Arbitration, (Kluwer Law International; Kluwer Law International 2013, Volume 30, Issue 2;

REsp n ${ }^{\circ}$ 251.438- RJ (2000/0024821-5), Min. Relator Barros Monteiro, Quarta Turma, STJ, Data de Publicação 02/10/2000;

REsp n 1168547/ RJ (2007/0252908-3), Min. Relator Luis Felipe Salomão, Quarta Turma, STJ, Data de Publicação 07/02/2011;

Agravo de Instrumento $N^{\circ} 70003003514$, Quinta Câmara Cível, Tribunal de Justiça do RS, Relator: Marco Aurélio dos Santos Caminha, Julgado em 13/09/2001; 
Agravo de Instrumento No 70023968704, Décima Segunda Câmara Cível, Tribunal de Justiça do RS, Relator: Judith dos Santos Mottecy, Julgado em 05/06/2008;

Apelação0160679-93.2005.8.19.0001 (2007.001.34305),Des. Luiz Fernando de Carvalho, 3a Câmara Cível, TJRJ, DJ 28/07/2009;

Apelação 0325793-06.2013.8.19.0001, Des. Rel. Claudio Dell'Orto, $18^{\mathrm{a}}$ Câmara Cível do TJRJ, DJ 26/09/2014;

Agravo de Instrumento 0005639-53.2007.8.19.0000 (2007.002.02478), Des.

Ricardo Rodrigues Cardozo, 15a Câmara Cível, TJRJ, DJ 27/03/2007;

Apelação 0219096-33.2008.8.26.0100, Rel. Rebello Pinho, 20a Câmara de Direito Privado, TJSP, DJ 05/08/2013;

Agravo de Instrumento 2072302-42.2013.8.26.0000, Rel. Teixeira Leite, 1a Câmara Reservada de Direito Empresarial, TJSP, DJ 03/04/2014;

Apelação/ Duplicata 0043542-60.2003.8.26.0100, Rel. Itamar Gaino, 21 ${ }^{\mathrm{a}}$ Câmara de Direito Privado, TJSP, DJ 19/05/2014;

Código de Processo Civil de 1973/ Lei 5.869 de 1973;

Protocolo de Buenos Aires sobre Jurisdição Internacional em Matéria

Contratual,/ Decreto 2.095 de 1996;

Regulamento 44/2001 da União Europeia;

Protocolo de Las Leñas de 1992,/ Decreto 6.891 de 2009;

Anteprojeto do Novo Código de Processo Civil, Brasília 2010;

WAMBIER, Teresa de Arruda Alvim; DANTAS, Bruno; FREIRE, Alexandre; NUNES, Marcelo Guedes. O Novo CPC dará maior racionalidade ao Sistema de Justiça. 12/07/2013. Disponível em <http://www.migalhas.com.br/dePeso/16,MI182384,41046$\mathrm{O}+$ novo $+\mathrm{CPC}+$ dara + maior+racionalidade+ao+sistema+de+Justica $>$. Acesso em 09.03.2015; 
<http://www.senado.gov.br/atividade/materia/detalhes.asp?p_cod_mate=97249 >. Acesso em 26.05.2015 às 16:45;

http://www.camara.gov.br/proposicoesWeb/fichadetramitacao?idProposicao=4 90267. Acesso em 26.05.2015 às 16:51;

$<$ http://www.sdh.gov.br/assuntos/adocao-e-sequestro-internacional/legislacaoe-publicacoes/a-conferencia-de-haia-de-direito-internacional-privado-aparticipacao-do-brasil>, p. 492-493 acesso em 15.03.2015 às 14:56;

<http://www.hcch.net/index_en.php?act=events.details\&year=2014\&varevent $=389>$ acesso em 09.05.2015 às 17h06;

<http://www.senado.gov.br/atividade/materia/getPDF.asp?t=83351\&tp=1> acesso em 18.05.2015 às 10:36.;

<http://www.senado.gov.br/atividade/materia/getTexto.asp?t=83642\&c=PDF\& tp=1> acesso em 18.05.2015 às 10:57;

<http://www.senado.gov.br/atividade/materia/getPDF.asp?t=83497\&tp=1> acesso em 18.05.2015 às 10:38.

<http://www.senado.gov.br/atividade/materia/getPDF.asp?t=83510\&tp=1> acesso em 18.05.2015 às 10:48

<http://www.senado.gov.br/atividade/materia/getPDF.asp?t=83984\&tp=1> acesso em 18.05.2015 às 10:50 <http://www.camara.gov.br/proposicoesWeb/prop_mostrarintegra?codteor=92 5536\&filename $=$ Tramitacao -

$\mathrm{EMC}+113 / 2011+\mathrm{PL} 804610+\% 3 \mathrm{D} \% 3 \mathrm{E}+\mathrm{PL}+8046 / 2010>$ Acesso em 18.05.2015 às 11:06;

<http://www.camara.gov.br/proposicoesWeb/prop_mostrarintegra?codteor=92 5536\&filename $=$ Tramitacao -

$\mathrm{EMC}+116 / 2011+\mathrm{PL} 804610+\% 3 \mathrm{D} \% 3 \mathrm{E}+\mathrm{PL}+8046 / 2010>$ Acesso em 18.05.2015 Às 11:06; 
<http://www.camara.gov.br/proposicoesWeb/prop_mostrarintegra?codteor=94 2272\&filename $=\mathrm{EMC}+429 / 2011+\mathrm{PL} 602505+\% 3 \mathrm{D} \% 3 \mathrm{E}+\mathrm{PL}+8046 / 2010>$ acesso em 18.05.2015 às 11:10 